\title{
Nitrogen fluxes, denitrification and the role of microphytobenthos in microtidal shallow-water sediments: an annual study
}

\author{
Kristina Sundbäck* ${ }^{*}$ Alison Miles, Eva Göransson \\ Department of Marine Botany, Göteborg University, PO Box 461, 40530 Göteborg. Sweden
}

\begin{abstract}
The annual cycle of oxygen and nitrogen flux, denitrification and microphytobenthic variables (primary production, biomass, composition and calculated $\mathrm{N}$ demand) were studied for 2 shallow-water microtidal sediment sites in NE Kattegat, 1 sandy and 1 silty, by incubating undisturbed sediment in the laboratory in light and darkness. Both sites ( 2 stations within each) were characterised by low concentrations of inorganic nitrogen (IN) in the overlying water during summer $\left(\mathrm{NO}_{3}\right.$ generally $<1 \mu \mathrm{M}$ ), with winter concentrations of 5 and $30 \mu \mathrm{M}$ for the sandy and silty site, respectively. Through the activity of microphytobenthos, the sediment systems appeared to be net autotrophic during most of the year. Net oxygen production varied between -400 and $6600 \mu \mathrm{mol} \mathrm{m}^{-2} \cdot \mathrm{h}^{-1}$, being highest during the warmest season. Although the composition of the microphytobenthos depended on the sediment type, it did not have a crucial effect on the magnitude of the microphytobenthic biomass or function. The temporal pattern of the function of the microalgal community, on the other hand, was significantly

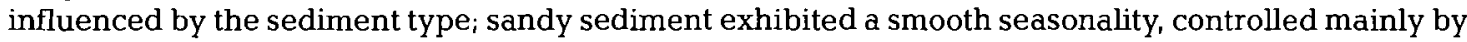
temperature and light, while the silty microtidal sediment was also controlled by stochastic events, such as sediment resuspension. Microphytobenthos had a significant effect on the IN flux, the clearest effect being found for $\mathrm{NH}_{4}$. Total denitrification (isotope-pairing technique) generally varied between $<1$ and $40 \mu \mathrm{mol} \mathrm{m}^{-2} \mathrm{~h}^{-1}$, being dominated by nitrification-coupled denitrification $\left(D_{\mathrm{n}}\right)$, and being 1 order of magnitude higher at the silty site. Microphytobenthic activity generally inhibited denitrification in the low- $\mathrm{N}$ areas in this study. The results suggest that the microphytobenthos functions as a major control throughout the annual cycle, by forming communities that are net photoautotrophic throughout the year, and by significantly influencing both the IN flux and denitrification rates. Sandy sediment appeared to function as an IN sink during winter and early spring, while no clear seasonal pattern was found for silty sediment. Calculated $\mathrm{N}$ demand of the microphytobenthos far exceeded the measured sediment net uptake of $\mathrm{N}$, supporting the idea that sandy systems in low-nitrogen areas can be highly productive through a closed recycling of $N$. The ratio between calculated microphytobenthic $\mathrm{N}$ demand and measured denitrification rates suggests that denitrification has a minor role as a $\mathrm{N}$ sink, particularly in sandy, cold-climate microtidal sediments.
\end{abstract}

KEY WORDS: Sediment $\cdot$ Nitrogen · Primary production $\cdot$ Denitrification $\cdot$ Microphytobenthos

\section{INTRODUCTION}

The role of sediments in nutrient cycling has primarily been studied from the standpoint of heterotrophic processes, such as bacterial and faunal activities. This may seem natural as the majority of marine sediments exist in constant darkness or dim light, but there are,

•E-mail: kristina.sundback@marbot.gu.se however, large coastal areas shallow or clear enough to enable photosynthesis to occur at the sediment surface (Marinelli et al. 1998 and references therein). Thus, for ecologically relevant results, nutrient and oxygen exchange between sediment and water in shallow waters must be measured in both light and darkness to account for the influence of photosynthetic organisms. The idea that the benthic microalgal community can function as a 'filter' that controls the flux of 
dissolved nutrients at the sediment/water interface was put forward some 20 yr ago (Henriksen et al. 1980, Blackburn \& Henriksen 1983). This 'filter' function is linked to at least 2 algal processes, algal assimilation of nutrients and photosynthetic oxygenation of the sediment surface, and has since then been shown in several studies (e.g. Krom 1991, Rizzo et al. 1992, Wiltshire 1992, Risgaard-Petersen et al. 1994, Reay et al. 1995, van Luijn et al. 1995, Sigmon \& Cahoon 1997 and references therein).

Shallow-water coastal sediments are recognised as highly productive areas which function as active buffer zones in the transport of nutrients between land and sea. However, our knowledge of the carbon and nutrient turnover in these sediments, particularly in microtidal areas, is still limited. The microtidal waters overlying sediments, for example, in the Baltic Sea and the Mediterranean, are often clear enough to allow photosynthesis down to $10 \mathrm{~m}$ or more during most of the light period (Sundbäck \& Jönsson 1988, Herndl et al. 1989). Although sea grasses and floating macroalgae can locally be important autochthonous primary producers for these sediments, benthic microphytes have by far the widest spatial and temporal distributions. In addition, the importance of microbenthic primary producers is not restricted to the warm season (Rysgaard et al. 1995. Sundbäck et al. 1996), as is the case for rooted macrophytes and ephemeral floating macroalgae (Pedersen \& Borum 1993, Pihl et al. 1996). These habitats differ in many aspects from those on tidal coasts. The sediments are permanently submerged, although the shallowest areas can occasionally be exposed to air during extreme low water caused by weather conditions and wind direction. Moreover, regular tidal flushing is lacking, a fact that has also led to the general

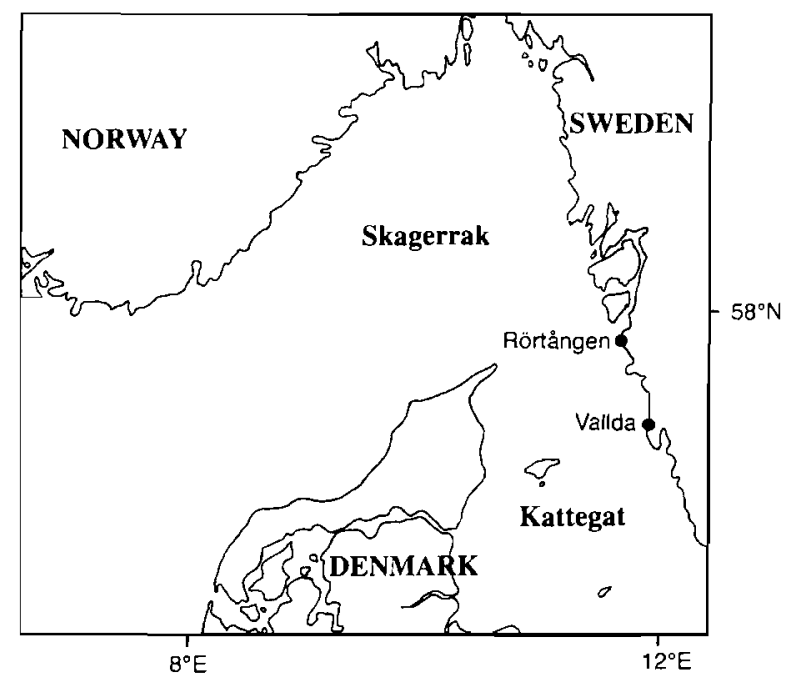

Fig. 1. Position of the 2 study sites, Vallda and Rörtången, on the west coast of Sweden view that non-tidal coasts are more vulnerable to pollution and eutrophication than tidal coasts (Rosenberg et al. 1990, Nixon 1995).

The objective of our study was to describe the annual variation in oxygen and nitrogen flux, and to identify the main potential controlling factors for a northernEuropean microtidal area where the microphytobenthos is the main source of primary production. The main hypothesis was that the microphytobenthos is a major factor controlling nutrient and oxygen fluxes, both spatially and temporally. A secondary aim was to provide a preliminary evaluation of the role of microtidal shallow-water sediments in the removal of nitrogen. Although the balance between different $\mathrm{N}$ removing processes, such as algal assimilation and denitrification, is a central issue related to proceeding eutrophication, these processes have seldom been actually measured concomitantly. The study involved monthly light and dark measurements of oxygen and nutrient fluxes, as well as sediment denitrification, applying a hierarchical sampling design. The main variables included fluxes of oxygen and dissolved inorganic $\left(\mathrm{NO}_{3}, \mathrm{NO}_{2}, \mathrm{NH}_{4}\right)$ and organic (DON) nitrogen, denitrification and the biomass, net productivity and composition of benthic microphytes.

\section{MATERIAL AND METHODS}

Study area. The study was conducted in 2 shallow brackish-water bays (salinity range 18 to 34 ) on the west coast of Sweden, at the transition between the Kattegat and Skagerrak (Fig. 1), with a tidal amplitude of only 10 to $20 \mathrm{~cm}$. Two sites, ca $50 \mathrm{~km}$ apart (Vallda, $57^{\circ} 29^{\prime} \mathrm{N}, 11^{\circ} 56^{\prime} \mathrm{E}$, and Rörtăngen, $57^{\circ} 55^{\prime} \mathrm{N}, 11^{\circ} 46^{\prime} \mathrm{E}$ ) were studied, one being dominated by silty sand and the other by sandy silt. Characteristics for the sites are given in Table 1. Although the tidal influence is negligible, water level fluctuations can be higher due to changing weather (Swedish Meteorological and Hydrological Institute, SMHI)

Sampling. Samples were taken once per month, on 11 occasions (12 for chlorophyll a [chl a] and oxygen flux) during the period March 1997 to February 1998. The sampling design was hierarchical, so that variability could be tested on 2 spatial scales (sites and stations). At both sites, 2 stations, ca $50 \mathrm{~m}$ apart, were sampled: Stns A and B at Vallda, and Stns C and D at Rörtången. Mean water depths at the sampling sites were 0.2 and $0.5 \mathrm{~m}$, respectively.

At each station, a minimum of 3 replicate samples were taken for each variable. The following samples were taken: in situ water samples, sediment cores (inner diameter [i.d.] $8 \mathrm{~cm}$ ) for flux measurements, chl $a$ and macrofauna, sediment cores $(i . d .=6.7 \mathrm{~cm})$ for 
measurement of oxygen penetration, sediment characteristics, microalgal biomass and species composition.

Nutrient samples of the overlying water $(n=5)$ were taken in situ with $50 \mathrm{ml}$ disposable syringes and filtered into $5 \mathrm{ml}$ disposable plastic vials through cellulose acetate syringe filters (Sartorius, pore size $0.45 \mu \mathrm{m})$. Samples were immediately frozen in liquid nitrogen and stored at $-80^{\circ} \mathrm{C}$. Samples for the measurement of oxygen concentration in the in situ water $(\mathrm{n}=5)$ were transferred into $12.5 \mathrm{ml}$ gas-tight vials (Exetainer, Labco Ltd, High Wycombe, UK) and Winkler reagents I and II immediately added. Samples were stored in the dark and analysed within $2 \mathrm{~d}$ of sampling. In situ measurements of temperature, salinity and light attenuation (Biospherical Instruments light meter) in the water were made. Sediment cores and incubation water for denitrification measurements were, for practical reasons, sampled on a second sampling tour ( 3 to $6 \mathrm{~d}$ after nutrient flux sampling). Depending on season (temperature), all flux measurements, including both sampling sites, were completed within a 1 to 2 wk period.

Measurements of oxygen and nutrient fluxes. Fluxes were measured under controlled laboratory conditions, applying standardised and intercalibrated techniques (Dalsgaard 2000). Incubations were carried out in the laboratory under light and dark conditions, at in situ temperature in site water. Fluxes of nutrients and oxygen were paired for light and dark incubations (i.e. measured on the same cores), with denitrification measurements carried out on separate cores (as cores are slurried at the completion of the incubation).

Sediment for flux measurements was sampled with $24 \mathrm{~cm}$ long plexiglass cores (i.d. $=8 \mathrm{~cm}$ ) leaving $12 \mathrm{~cm}$ of overlying water. The cores from each site were randomly distributed within an incubation tank containing approx. $70 \mathrm{l}$ of unfiltered water from the respective site. The tank water was continuously circulated using an Eheim pump (flow $201 \mathrm{~min}^{-1}$ ) and water movement in the cores was provided by Teflon-coated magnets $16 \mathrm{~cm}$ above the sediment surface, turning rate of 60 to $70 \mathrm{rpm})$. This ensured thorough mixing of the water without causing sediment resuspension. The cores were left overnight without lids. On the following day, cores were pre-incubated at the experimental irradiance level for $1 \mathbf{h}$ and then the headwater in the cores was exchanged before incubations were started. Three cores from each station within a site, together with 1 or 2 control cores (overlying water only), were incubated in each tank. Light and dark incubations were run on the same cores on consecutive days.

Incident irradiance was provided by individual 25 or $50 \mathrm{~W}$ halogen bulbs placed directly over each core and layers of gauze were used as neutral filters to adjust the level of irradiance. The light intensity used repre- sented the daily mean for that month (values for 1995 from Danish Institute of Agricultural Sciences, Research Center Foulum, Denmark) and varied between 86 and $618 \mu \mathrm{mol}$ photons $\mathrm{m}^{-2} \mathrm{~s}^{-1}$. Light incubations were run over the natural daylight period. Incubation time was set so that changes in oxygen concentration within the cores did not exceed $20 \%$. Flux times varied between 1 and $21 \mathrm{~h}$, depending on the season (temperature).

Oxygen was analysed by Winkler titration (Strickland \& Parsons 1972). Inorganic nutrients $\left(\mathrm{NO}_{3}, \mathrm{NO}_{2}\right.$, $\mathrm{NH}_{4}, \mathrm{PO}_{4}$, and $\left.\mathrm{Si}(\mathrm{OH})_{4}\right)$ were analysed on a TRAACS 800 autoanalyser (Braun \& Lubbe) using standard colourimetric methods (Grasshoff et al. 1983). DON was oxidized to $\mathrm{NO}_{3}$ according to the method of Valderrama (1981).

Denitrification. Sediment denitrification was measured using the isotope pairing technique (Nielsen 1992), which discriminates between denitrification supported by $\mathrm{NO}_{3}$ in the water column $\left(D_{\mathrm{w}}\right)$ and nitrification-coupled denitrification $\left(D_{n}\right)$. Measurements were performed on 1 set of cores in light and 1 set in darkness. At the start of the experiment, ${ }^{15} \mathrm{NO}_{3}{ }^{-}$ (100 mM Na ${ }^{15} \mathrm{NO}_{3}{ }^{-}, 99.6$ atom \%, Europa Scientific Ltd) was added to the headspace water to a final concentration of $\sim 60 \mu \mathrm{M}^{15} \mathrm{NO}_{3}{ }^{-}\left(\sim 90 \%{ }^{15} \mathrm{NO}_{3}\right)$. The $\mathrm{NO}_{3}{ }^{-}$ concentration was measured prior to the addition of ${ }^{15} \mathrm{NO}_{3}{ }^{-}$and at the time that the cores were closed (within $0.5 \mathrm{~h}$ of the addition of ${ }^{15} \mathrm{NO}_{3}{ }^{-}$), in order to calculate the ${ }^{14} \mathrm{~N} /{ }^{15} \mathrm{~N}$ ratio in the $\mathrm{NO}_{3}{ }^{-}$pool. For extraction of the $\mathrm{N}_{2}$ samples, $2 \mathrm{ml} \mathrm{ZnCl}{ }_{2}\left(1 \mathrm{~g} \mathrm{ml}^{-1}\right)$ was added to the water phase and then the sediment and water were gently but quickly mixed. Part of the slurry was then transferred to a $12.5 \mathrm{ml}$ gas-tight vial. The ${ }^{14} \mathrm{~N}^{15} \mathrm{~N}$ and ${ }^{15} \mathrm{~N}^{15} \mathrm{~N}$ abundance in $\mathrm{N}_{2}$ was analysed by mass spectrometry at the National Environmental Research Agency, Silkeborg, Denmark. The rate of denitrification was calculated according to the procedures and assumptions of Nielsen (1992).

Chl a. Samples for chl a and pheopigment content (surface $5 \mathrm{~mm}$ ) were taken from the sediment cores on completion of the nutrient flux measurements with a $20 \mathrm{ml}$ cut-off disposable syringe. Pigment concentration was measured spectrophotometrically (Lorenzen 1967 ) in frozen samples after extraction with $90 \%$ acetone.

Microalgal biomass and composition. The nonattached ('epipelic') and attached ('epipsammic') fractions from 2 pooled samples (i.d. $=8.7 \mathrm{~mm}$ ) from each core were counted using epifluorescence microscopy as previously described by Sundbäck et al. (1996). The latter were detached by ultrasonication $(9 \mathrm{~min}$, $35 \mathrm{kHz})$. As the range of cell sizes was large $(<2$ to $500 \mu \mathrm{m})$, different magnifications were used for different size categories in order to avoid a bias caused 
by the counting method. Cells were grouped, when possible, to species or genus level, and otherwise into size and shape groups and cell volumes calculated (for further details, see Sundbäck et al. 1996).

Macrofauna. After taking the chlorophyll samples from the incubation cores, the entire sediment content of each core was wet sieved $(500 \mu \mathrm{m}$ mesh size). Fauna was stored in formalin for later identification and measurements of wet weight.

Sediment characteristics. The depth of the oxic zone in the sediment was measured using oxygen microelectrodes (Revsbech 1989). Porosity (water content) for the top $5 \mathrm{~mm}$ sediment was measured by standard methods, and grain size distribution was analysed by dry sieving of the sediment. Loss on ignition was determined after $2 \mathrm{~h}$ at $500^{\circ} \mathrm{C}$.

Data analyses. Differences between sites and stations were tested using 2way ANOVA (unnested and nested), with place and time and treatment (light/dark) and time as main factors. Some comparisons were made using 1-way ANOVA. Homogeneity of variances was tested using Cochran's test, and when variances were found to be heterogeneous, the data were transformed according to Underwood (1997). Differences were accepted as significant at $\mathrm{p}<0.05$. Pearson correlation analyses were used to look for correlations between variables.

\section{RESULTS}

\section{Physical characteristics of sites}

The 2 sites differed as to sediment type; the sediment at Vallda was silty sand, while the Rörtången site consisted of sandy silt (Table 1). During summer (July to August), the sediment at Vallda was exposed to the air during periods of high pressure, whereas the Rörtången site remained immersed. The water column at the latter site was often turbid due to wind-driven sediment resuspension. Water temperature varied between -1 and $30^{\circ} \mathrm{C}$, with water temperatures below $10^{\circ} \mathrm{C}$ for the period November to April. Both sites were covered by ice during the period January to March.
Table 1. Characteristics of the Vallda and Rörtangen sites. Values shown are the range or mean $\pm \mathrm{SE}$ for each site, averaged over the 12 mo of the study

\begin{tabular}{|c|c|c|}
\hline & Vallda & Rörtången \\
\hline \multicolumn{3}{|l|}{ Physical properties } \\
\hline Water depth (m) & $0.2-0.5$ & $0.5-0.75$ \\
\hline Salinity (PSU) & $20-34$ & $18-31$ \\
\hline Water temperature $\left({ }^{\circ} \mathrm{C}\right)$ & $-1-30$ & $-1-27$ \\
\hline \multicolumn{3}{|l|}{ Sediment properties } \\
\hline Size fractions $(\%):>250 \mu \mathrm{m}$ & $13 \pm 1$ & $24 \pm 3$ \\
\hline \multirow{2}{*}{$\begin{array}{l}(\mathbf{n}=10) \quad \begin{array}{r}63-250 \mu \mathrm{m} \\
<\end{array} \quad 63 \mu \mathrm{m}\end{array}$} & $67 \pm 5$ & $31 \pm 3$ \\
\hline & $20 \pm 6$ & $45 \pm 6$ \\
\hline Loss-on-ignition $(\%)$ & $\begin{aligned} 1.4 & \pm 0.08 \\
(\mathrm{n} & =6)\end{aligned}$ & $\begin{array}{l}4.9 \pm 0.7 \\
(\mathrm{n}=6)\end{array}$ \\
\hline $\begin{array}{l}\text { Porosity } \\
(0-0.5 \mathrm{~cm} \text { depth })\end{array}$ & $\begin{array}{r}0.2 \pm 0.0 \\
(\mathrm{n}=11)\end{array}$ & $\begin{aligned} 0.5 & \pm 0.04 \\
(\mathrm{n} & =10)\end{aligned}$ \\
\hline Oxygen penetration depth in light (mm) & $\begin{array}{r}3.2 \pm 0.3 \\
(\mathrm{n}=10)\end{array}$ & $\begin{array}{r}1.6 \pm 0.1 \\
(\mathrm{n}=10)\end{array}$ \\
\hline \multicolumn{3}{|c|}{ Chemical characteristics of overlying water } \\
\hline $\mathrm{O}_{2}\left(\mu \mathrm{mol} \mathrm{l}{ }^{-1}\right)$ & $\begin{aligned} 338 & \pm 5 \\
(\mathrm{n} & =120)\end{aligned}$ & $\begin{array}{l}343 \pm 5 \\
(\mathrm{n}=120)\end{array}$ \\
\hline $\mathrm{NO}_{3}+\mathrm{NO}_{2}\left(\mu \mathrm{mol} \mathrm{l} l^{-1}\right)$ & $\begin{aligned} 1.7 & \pm 0.2 \\
(\mathrm{n} & =102)\end{aligned}$ & $\begin{array}{r}9.1 \pm 1.1 \\
(\mathrm{n}=97)\end{array}$ \\
\hline $\mathrm{NH}_{4}\left(\mu \mathrm{mol} \mathrm{l}^{-1}\right)$ & $\begin{aligned} 1.7 & \pm 0.1 \\
(\mathrm{n} & =103)\end{aligned}$ & $\begin{array}{l}2.7 \pm 0.2 \\
(\mathbf{n}=105)\end{array}$ \\
\hline $\operatorname{DON}\left(\mu \mathrm{mol} \mathrm{l}^{-1}\right)$ & $\begin{aligned} 23.2 & \pm 1.1 \\
(\mathrm{n} & =103)\end{aligned}$ & $\begin{aligned} 24.9 & \pm 1.1 \\
(\mathrm{n} & =94)\end{aligned}$ \\
\hline $\mathrm{PO}_{4}\left(\mu \mathrm{mol} \mathrm{l}{ }^{-1}\right)$ & $\begin{array}{r}0.13 \pm 0.01 \\
(\mathrm{n}=103)\end{array}$ & $\begin{array}{r}0.18 \pm 0.01 \\
(\mathbf{n}=106)\end{array}$ \\
\hline $\mathrm{SiO}_{2}\left(\mu \mathrm{mol} \mathrm{l}^{-1}\right)$ & $\begin{aligned} & 8.5 \pm 0.8 \\
&(\mathrm{n}=104)\end{aligned}$ & $\begin{aligned} 17.2 & \pm 1.1 \\
(\mathrm{n} & =106)\end{aligned}$ \\
\hline IN/IP molar ratio (December) & 26 & 83 \\
\hline \multicolumn{3}{|l|}{ Sediment microalgae (surface $5 \mathbf{~ m m}$ ) } \\
\hline Biomass (carbon) (mg C m$\left.{ }^{-2}\right)$ & $826(407-1354)$ & $752(103-2384)$ \\
\hline Biomass (chl a) (mg chl $a \mathrm{~m}^{-2}$ ) & $\begin{aligned} 54.4 & \pm 2.9 \\
(\mathrm{n} & =66)\end{aligned}$ & $\begin{array}{r}34.8 \pm 2.2 \\
(\mathrm{n}=66)\end{array}$ \\
\hline
\end{tabular}

Oxygen penetration into the sediment was generally greater at the sandier Vallda site than at Rörtången (Table 1). Organic content (loss on ignition) was ca 3.5 times higher at the silty site than at the sandy site (Table 1).

\section{Algal biomass}

Chl a content of the sediment varied between 16 and $106 \mathrm{mg} \mathrm{m}^{-2}$ (mean monthly values). There was a significant difference in the temporal pattern of microalgal biomass between the 2 sites (site $\times$ time interaction, $\mathrm{p}=0.018$ ), with concentrations generally higher at Vallda (sandy) than Rörtangen (silty), with the exception of October (Fig. 2). At Vallda, chl a values peaked in March 1997, perhaps in association with the disap- 
a Vallda Stns $A$ and B

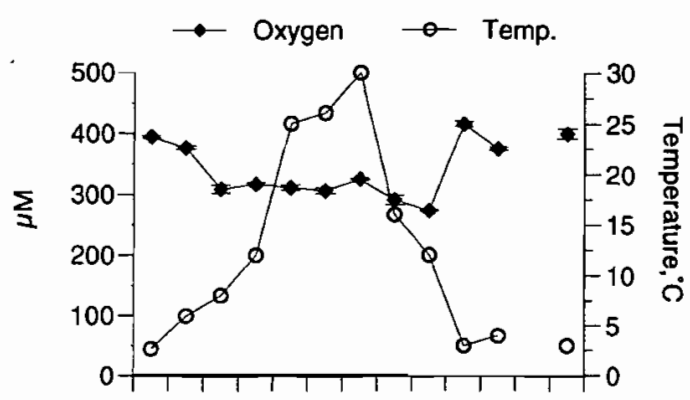

- Oxygen flux
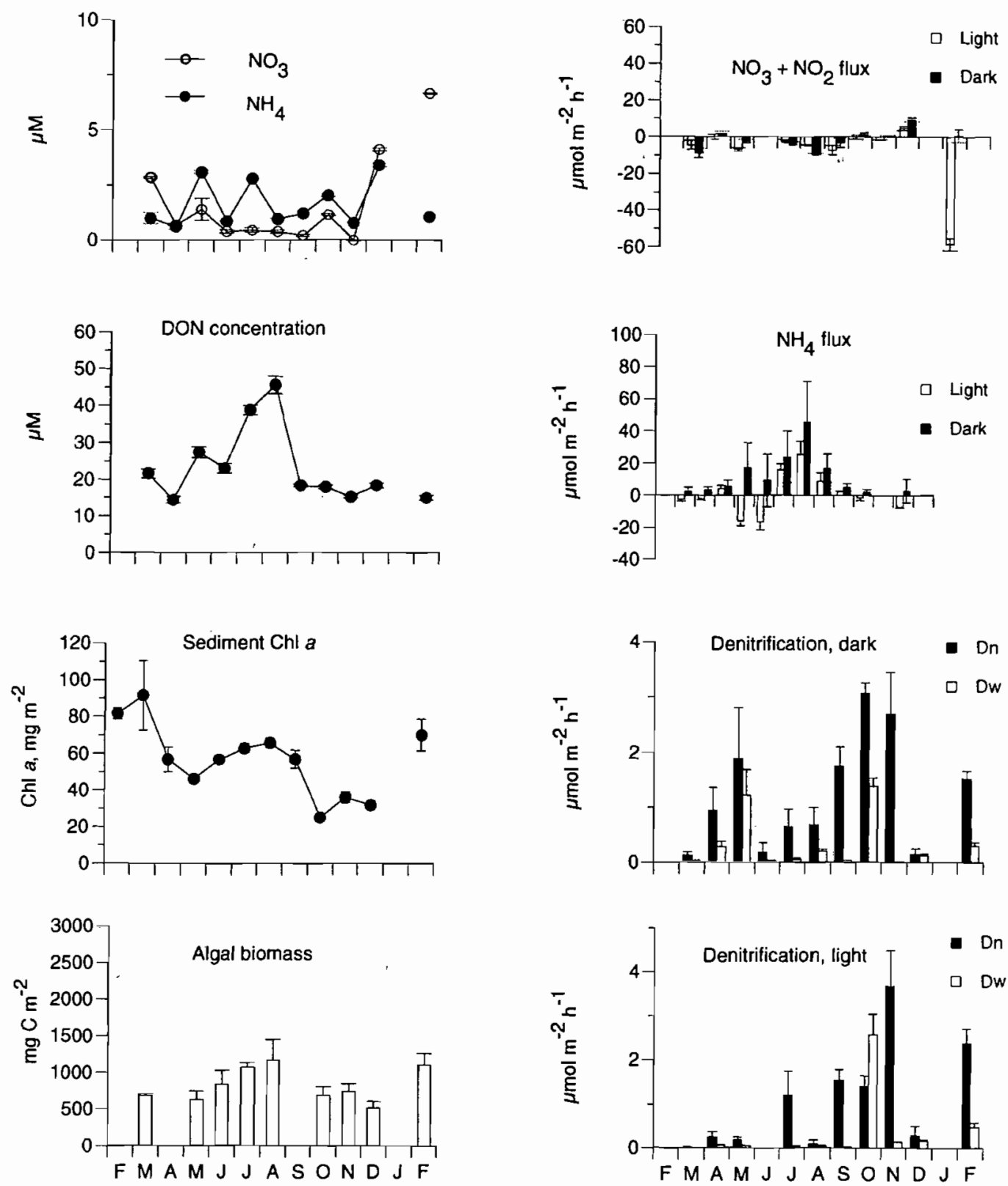

Fig. 2. (Above and on the following 2 pages.) Annual cycle of variables measured at (a) Vallda Stns A and B, (b) Rörtången Stn C, and (c) Rörtången Stn D. Values for Stns A and B are shown together (a), as there were no significant differences between the 2 stations. Values shown are mean $+S_{;} n=6$ in (a), and $n=3$ in (b) and (c); for in situ nutrients, $n=10$ in (a) and $n=5$ in (b) and (c) 


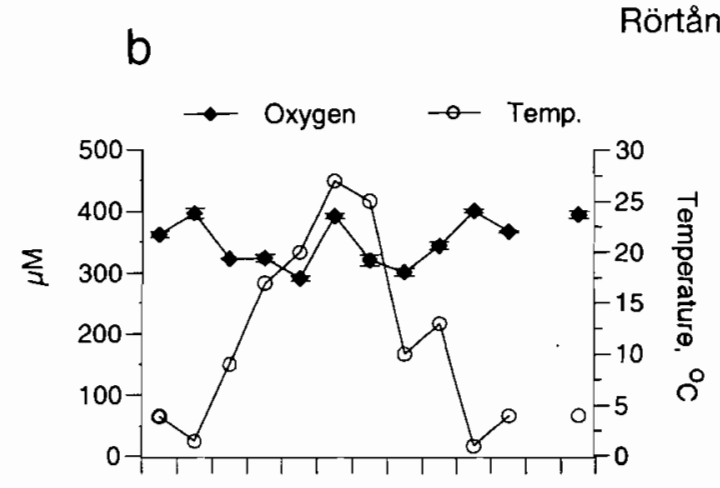

Rörtången Stn C
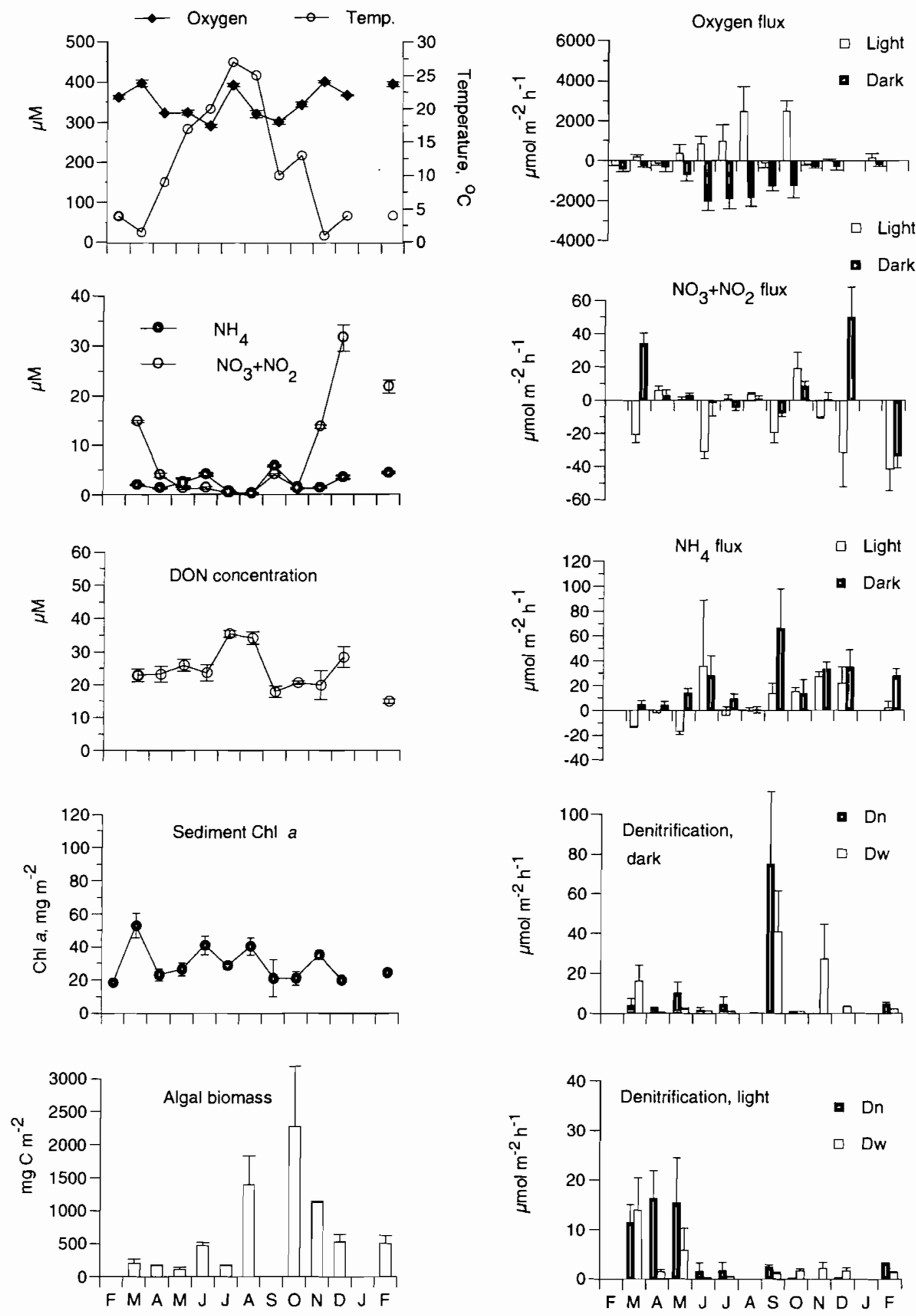

Fig. 2. (continued) 


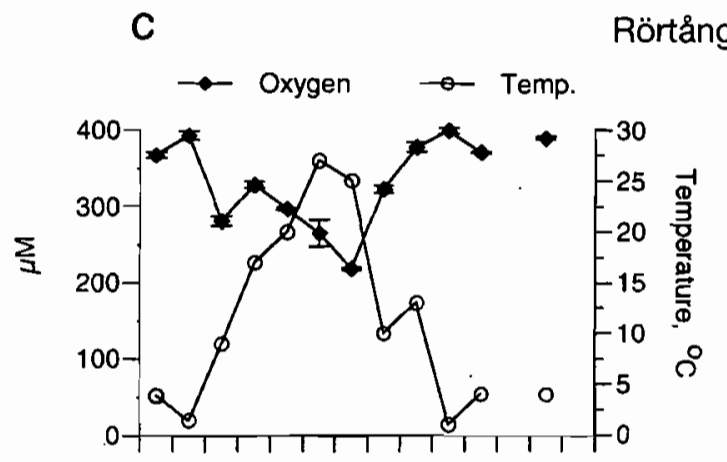

Rörtången Stn D
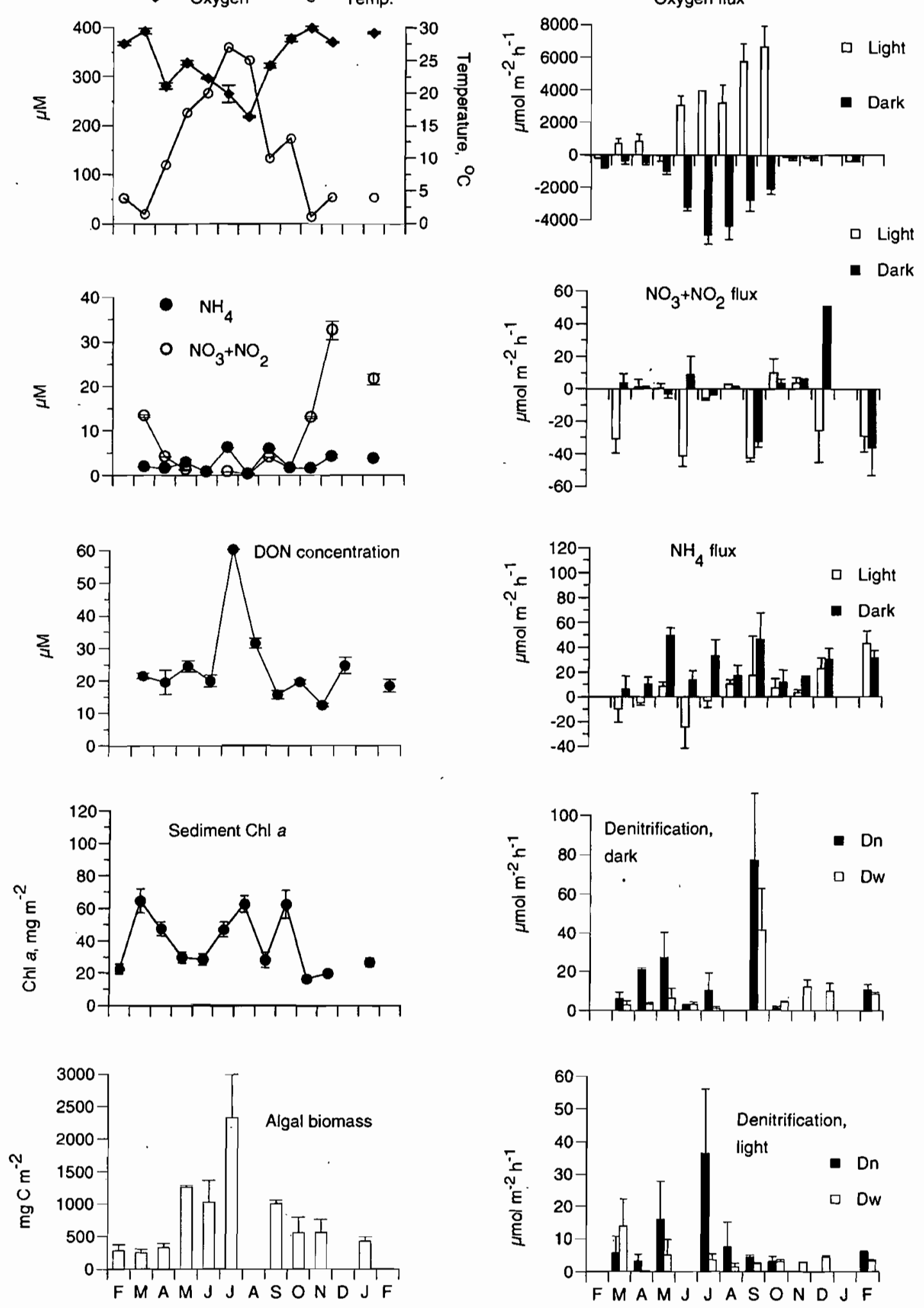

Fig. 2. (continued) 
pearance of ice and increased irradiance. Chl $a$ values exhibited no significant variation over time $(p=0.1957)$ at the site level at Rörtången, although variations did occur between stations (Stns $C$ and D) $(p=0.0009$ ). Chlorophyll peaks at Rörtången often coincided with the re-settlement of sediment (and resulting increased light penetration) following wind-induced sediment resuspension. This was seen as a significant positive correlation $(\mathrm{p}<0.05)$ at Stn $\mathrm{D}$ between chl $a$ and the difference between the mean wind speed of the $3 \mathrm{~d}$ preceding sampling (arbitrarily chosen to reflect 'disturbance history') and that of the sampling day. For Stn $\mathrm{C}$, the high heterogeneity of the sediment is thought to have masked this correlation. Mean monthly values for pheopigment content varied between 60 and $183 \mathrm{mg}$ $\mathrm{m}^{-2}$, and always exceeded chl a values. The ratio pheopigment/chl a showed an increasing trend from early spring to late autumn.

Algal biomass based on cell counts varied between 103 and $2330 \mathrm{mg} \mathrm{C} \mathrm{m}^{-2}$. There was no overall difference between the 2 sites, but the seasonal pattern differed significantly (2-way ANOVA, site $x$ time interaction, $\mathrm{p}=0.008$ ) (Fig. 2). As for chl $a$, Stns $\mathrm{C}$ and $\mathrm{D}$ at Rörtången showed different temporal patterns. There was a significant positive correlation between microalgal biomass and temperature for the Vallda site, but not for the Rörtången site (Fig. 3). Microalgal composition was different at the 2 sites. Diatoms $<50 \mu \mathrm{m}$ in length, particularly epipsammic life forms, dominated at the Vallda site (sandy), whilst at the Rörtången site (silty sediment), large ( $>50 \mu \mathrm{m})$, particularly sigmoid, epipelic diatoms dominated. Moreover, colony-forming cyanobacteria Merismopedia and Microcrocis spp. were common at the Vallda site, but not at the Rörtången site.

\section{Macrofaunal biomass}

Fresh weight (FW) of macroscopic infauna peaked in August at Vallda (ca $50 \mathrm{~g} \mathrm{FW} \mathrm{m}^{-2}$ ), but later in the autumn at Rörtången, with peak values of 70 to $90 \mathrm{~g} \mathrm{FW}$ $\mathrm{m}^{-2}$ in October to November. The biomass of mudsnails Hydrobia spp., important grazers of microphytobenthos and abundant at Vallda in spring, may have been underestimated as the snails moved out of the cores (via sampling holes) during the incubations. Molluscs dominated the infaunal biomass in spring, while various taxa of burrowing worms dominated later in the year.

\section{In situ nutrient status of the sites}

The $\mathrm{NO}_{3}+\mathrm{NO}_{2}$ concentrations in the overlying water showed a significant seasonality at both sites, with highest values being found during winter (November to February), while summer concentrations were $<1 \mu \mathrm{M}$ (Fig. 2). Concentrations of both $\mathrm{NO}_{3}+\mathrm{NO}_{2}$ and $\mathrm{NH}_{4}$ were significantly higher at Rörtången ( $\mathrm{p}=$ $0.0245, p=0.0004$, respectively). Winter values of $\mathrm{NO}_{3}+\mathrm{NO}_{2}$ were 5 times higher at Rörtången $(30 \mu \mathrm{M})$ than at Vallda (ca $6 \mu \mathrm{M}$ ). $\mathrm{NO}_{2}$ represented between 3 and $20 \%$ (Vallda) and 1 and $9 \%$ (Rörtangen) of the combined $\mathrm{NO}_{3}+\mathrm{NO}_{2}$, with concentrations undetectable during summer. Mean monthly $\mathrm{NH}_{4}$ concentrations varied between 0.5 and $3.6 \mu \mathrm{M}$ at Vallda and between 0.2 and $6.2 \mu \mathrm{M}$ at Rörtången, with peak values at Rörtången in summer and autumn (Fig. 2).

DON dominated the $\mathrm{N}$ pool of the overlying water for the majority of the year and showed a significant seasonality $(p=0.0001)$. Concentrations varied from ca 15 to $20 \mu \mathrm{M}$ in winter, spring and autumn, with peak values (at Rörtången) of up to $60 \mu \mathrm{M}$ in summer (July to August) (Fig. 2). Concentrations were similar between the 2 sites with the exception of a substantial increase in July at Stn D, Rörtången, resulting in a significant difference between the sites $(p=0.0258)$.

Inorganic phosphorus concentrations were low all year round (undetectable to $0.4 \mu \mathrm{M}$ ), being at the limit of detection in summer and autumn. Silica concentrations varied between ca 1 and $30 \mu \mathrm{M}$, with peaks during summer and autumn and winter concentrations significantly higher at Rörtången than at Vallda (not shown).

\section{Oxygen flux}

Despite different sediment types, neither net oxygen production (range -400 to $6600 \mu \mathrm{mol} \mathrm{m}^{-2} \mathrm{~h}^{-1}$ ) nor community respiration (range 150 to $4900 \mu \mathrm{mol} \mathrm{m}^{-2} \mathrm{~h}^{-1}$ ) varied significantly on the site scale (ANOVA; $p=$ 0.678 and 0.941, respectively) (Fig. 2). However, oxygen flux varied significantly between stations at Rörtången, with lower fluxes at Stn C.

Oxygen flux (see also 'Effect of benthic microalgae on fluxes and denitrification' below) both in the light (net primary production, NP) and in the dark (total community respiration, CR) showed a seasonality at both sites, although the seasonal pattern was clearer at the Vallda site (Fig. 2). At Rörtången, oxygen fluxes increased through the spring and summer to a maximum in the autumn $\left(6657 \mu \mathrm{mol} \mathrm{m}^{-2} \mathrm{~h}^{-1}\right)$ before a sudden decrease in November. This pattern was not consistent with that seen at Vallda and was thought to result from physical disturbance of the sediment due to wind speeds $>15 \mathrm{~m} \mathrm{~s}^{-1}$ in the week prior to sampling. Stn C Rörtången also showed no net oxygen production in September and this is believed to be linked to sediment movement (see 'Discussion'). At both sites, $\Delta \mathrm{O}_{2}$ (light-dark flux rate) showed a significant positive 
Vallda $(A+B)$, sand
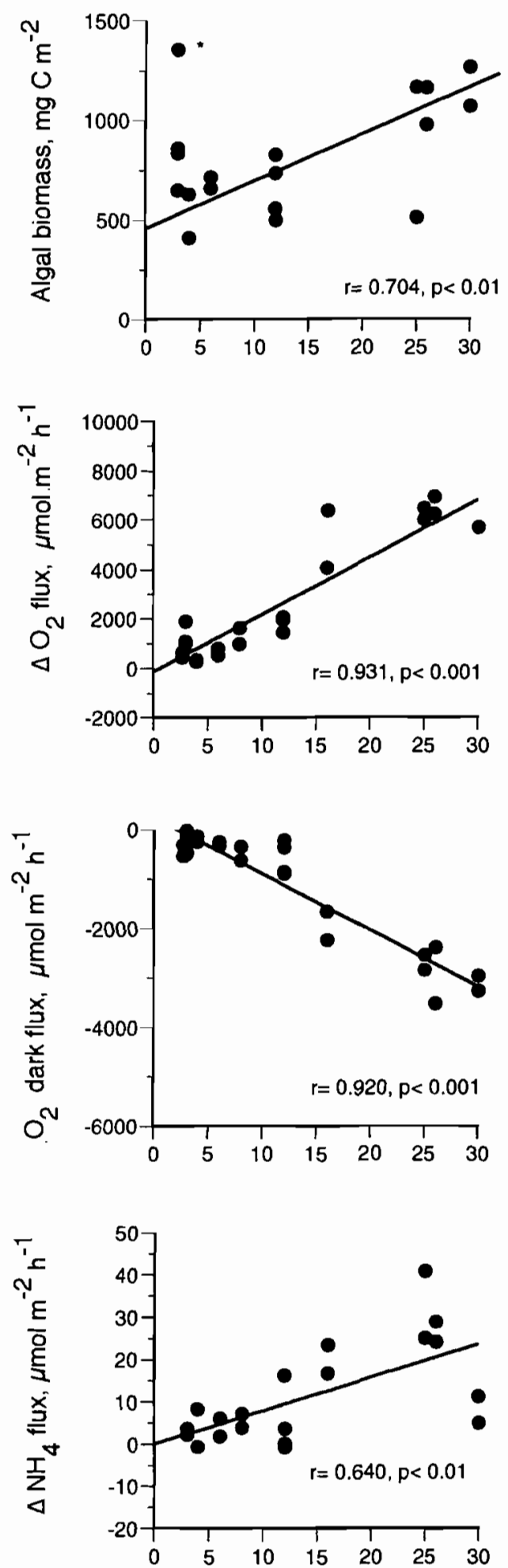

Rörtången $(C+D)$, silt
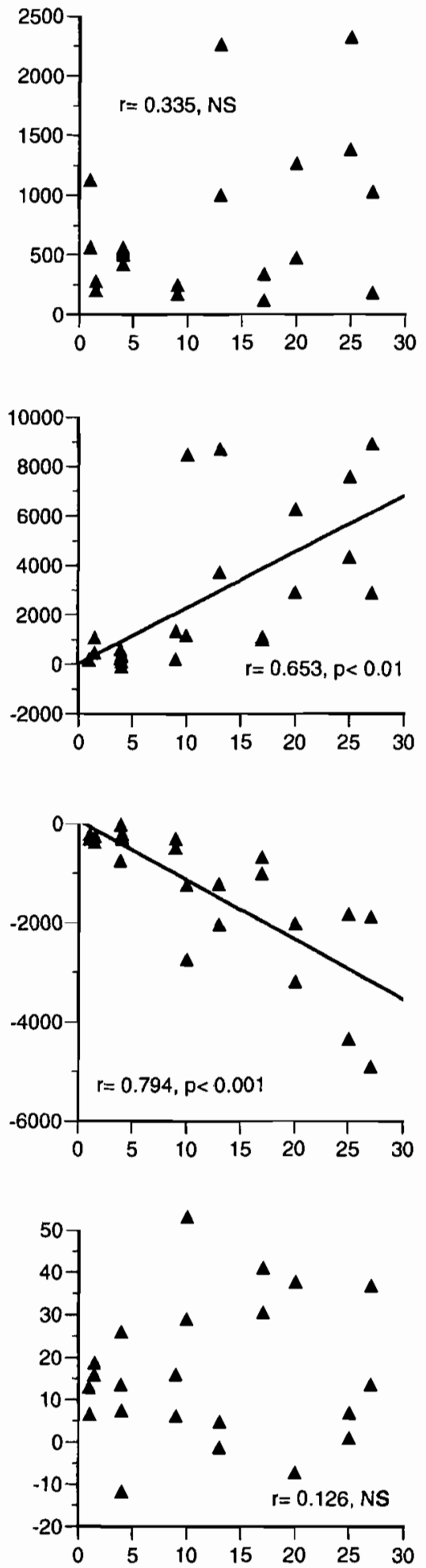

Temperature, ${ }^{\circ} \mathrm{C}$

Fig. 3. Correlations between temperature, and mean monthly values for algal biomass, $\Delta \mathrm{O}_{2}$ flux (light - dark oxygen flux), $\mathrm{O}_{2}$ flux in the dark (= community respiration) and $\Delta \mathrm{NH}_{4}$ flux (dark - light flux) for the 2 sites (including 2 stations per site). NS: not significant. Point not included in the correlation 
correlation with temperature (see Fig. 4), although there was a significant correlation with irradiance only at Vallda. A seasonal pattern in $\mathrm{CR}\left(\mathrm{O}_{2}\right.$ dark flux $)$ was also obvious at both sites, being highly positively correlated ( $p<0.001)$ with temperature.

\section{Nitrogen flux}

Fluxes of inorganic nitrogen (IN) generally appeared higher at Rörtången compared to Vallda (Fig. 2), but a significant interaction term (2-way ANOVA) for both $\mathrm{NH}_{4}$ and $\mathrm{NO}_{3}+\mathrm{NO}_{2}$ flux suggested that the difference between sites depended on season. Mean fluxes of $\mathrm{NH}_{4}$ varied between -25 and $+70 \mu \mathrm{mol} \mathrm{m} \mathrm{m}^{-2} \mathrm{~h}^{-1}$ and mean $\mathrm{NO}_{3}+\mathrm{NO}_{2}$ fluxes between -60 and $+50 \mu \mathrm{mol} \mathrm{m}{ }^{-2}$ $\mathrm{h}^{-1}$, but the latter values were generally much lower $\left(-10\right.$ to $+10 \mu \mathrm{mol} \mathrm{m} \mathrm{m}^{-2} \mathrm{~h}^{-1}$ ) (Fig. 2).

$\mathrm{NH}_{4}$ fluxes were generally directed out of the sediment, with higher fluxes in the dark than the light. Some uptake of $\mathrm{NH}_{4}$ in the light, suggesting an algal influence, did occur, mainly in the early part of the year. The $\Delta \mathrm{NH}_{4}$ flux (light-dark flux rate) at Vallda was positively and significantly correlated with temperature $(p<0.01)$, but a clear seasonality was not seen at Rörtången (Fig. 2). At Vallda, no significant differences in monthly fluxes of $\mathrm{NO}_{3}+\mathrm{NO}_{2}$ were detected until February 1998, when a significantly larger uptake in the light coincided with maximal in situ $\mathrm{NO}_{3}+\mathrm{NO}_{2}$ concentrations in the overlying water. Fluxes of $\mathrm{NO}_{3}+\mathrm{NO}_{2}$ at Rörtången varied significantly with time but there was no clear seasonal pattern.

DON fluxes also appeared to follow a seasonal pattern at Vallda, with maximal outfluxes in May to August. However, values (approximately -240 to $+260 \mu \mathrm{mol} \mathrm{m} \mathrm{m}^{-2} \mathrm{~h}^{-1}$ ) must be regarded as preliminary due to methodological problems and a large variation between replicate cores. Patterns of DON at Rörtången were hard to distinguish, especially regarding the highly disturbed Stn C, although Stn D did seem to indicate higher summer fluxes.

\section{Denitrification}

Total denitrification ( $D_{\text {tot }}$ ) values varied between 0.02 and $40 \mu \mathrm{mol} \mathrm{m} \mathrm{m}^{-2} \mathrm{~h}^{-1}$, although dark $D_{\text {tot }}$ values $>100 \mu \mathrm{mol} \mathrm{m} \mathrm{m}^{-2} \mathrm{~h}^{-1}$ were recorded at the silty site in September (Fig. 2). Rates for nitrification-coupled denitrification $\left(D_{\mathrm{n}}\right)$ and denitrification based on $\mathrm{NO}_{3}$ in the overlying water $\left(D_{w}\right)$, and consequently for $D_{\text {tot }}$, were higher in the silty sediment when compared with the sandy sediment, but a significant site $\times$ time interaction (2-way ANOVA) showed that this depended on season. Generally, $D_{\mathrm{n}}$ dominated over $D_{\mathrm{w}}$, highest propor- tions of $D_{\mathrm{n}}$ being found in summer. At Vallda, $D_{\mathrm{n}}$ (light and dark] constituted on average 70 to $80 \%$ of $D_{\text {tot }}$ throughout the year, and 57 to $69 \%$ at Rörtången.

Denitrification rates $\left(D_{\mathrm{n}}, D_{\mathrm{w}}\right.$ and $\left.D_{\text {tot }}\right)$ all exhibited a significantly different seasonal pattern at the 2 sites (2-way ANOVA, site $\times$ month interaction, $p<0.01$ ) and this was most obvious for the light values (Fig. 2). At the Vallda site, the highest light values for $D_{\text {tot }}$ and $D_{\mathrm{n}}$ were found in autumn, while at Rörtången these rates were generally highest in the spring. For dark values, the different pattern between sites was not as clear.

Denitrification did not correlate significantly with temperature or light, but $D_{\mathrm{w}}$ (light and dark), showed a significant correlation with water column $\mathrm{NO}_{3}$ at both sites. Few significant correlations were found between $D_{\text {tot }}$ and flux variables when data for the whole study period were included, but when data were split into low ( $<1$ for Vallda and $<5 \mu \mathrm{mol} \mathrm{m} \mathrm{m}^{-2} \mathrm{~h}^{-1}$ for Rörtången) and high rates, several significant negative correlations with oxygen flux appeared for the higher values.

\section{Effect of benthic microalgae on fluxes and denitrification}

\section{Oxygen}

Benthic microphytes had a large effect on oxygen fluxes, and through their activity the sediment systems were net oxygen producing (autotrophic) during most of the year (Fig. 2). Applying the 2 trophic indices Trophic Oxygen State Index (TOSI; Viaroli et al. 1996) and the Benthic Trophic State Index (BTSI; Rizzo et al. 1996), based on net oxygen production and community respiration, shows that both sites can be categorised as net autotrophic to highly autotrophic (BTSI 2-3) (Fig. 4).

\section{Nitrogen}

Microphytes significantly influenced fluxes of IN by decreasing the efflux at both sites, and occasionally resulting in uptake in the light (Figs. 2 \& 5). At all 4 stations, there were significant differences between light and dark fluxes for both $\mathrm{NH}_{4}$ and $\mathrm{NO}_{3}+\mathrm{NO}_{2}$, although for $\mathrm{NO}_{3}+\mathrm{NO}_{2}$ the effects depended on season (significant treatment $\times$ time interaction) (Fig. 2). NP and $\Delta \mathrm{NH}_{4}$ and $\triangle \mathrm{IN}\left(\mathrm{NO}_{3}+\mathrm{NO}_{2}+\mathrm{NH}_{4}\right)$ fluxes showed significant positive correlation at the Vallda site, but not at the Rörtången site (Fig. 6). Vallda appeared to be a sink for IN in light during the period March to July, mean annual uptake being 6 to $7 \mu \mathrm{mol} \mathrm{m} \mathrm{m}^{-2} \mathrm{~h}^{-1}$ (Table 2). The pattern for Rörtången was more erratic, but still exhibited an average annual uptake in light (4 to $8 \mu \mathrm{mol} \mathrm{N} \mathrm{m}^{-2} \mathbf{h}^{-1}$ ) (Table 2). 
Fig. 4. Trophic Oxygen State Index (TOSI; Viaroli et al. 1996) and Benthic Trophic State Index (BTSI; Rizzo et al. 1996) based on net community production and net community respiration shown for Vallda and Rörtången. Categories of BTSI: 0 = fully heterotrophic, 1 = net heterotrophic, 2 = net photoautotrophic, $3=$ highly photoautotrophic

\section{Denitrification}

An effect of light on denitrification was shown by the different temporal pattern in light and dark (2-way ANOVA, significant treatment $\times$ time interaction). Generally, dark rates exceeded rates in the light, with more significant light/dark effects being found for Rörtången. No significant effect of light on $D_{\text {tot }}$ was found for the Vallda site, but a significant interaction term was found for $D_{\mathrm{w}}$ at both stations (Stns A and B). At the Rörtången site, $D_{\text {tot }}$ showed a significantly different temporal pattern at the 2 stations. At Stn $D$, dark rates were higher both in spring and autumn. However, at Stn C, light values were higher in spring and dark values in autumn.

\section{DISCUSSION}

\section{Nutrient status}

The inorganic nutrient concentrations of the overlying water for the sites studied were generally low. This is typical of the surface waters of the Swedish west coast, where nitrogen has generally been found to be the most limiting nutrient for plankton production for the majority of the year (Granéli et al. 1990). Nitrogen
Vallda (sand)
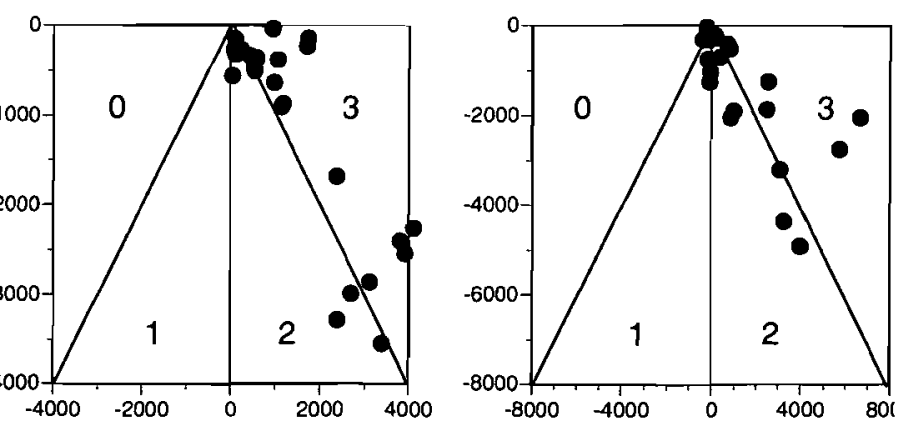

Net oxygen production, $\mu \mathrm{mol} \mathrm{m}^{-2} \mathrm{~h}^{-1}$

Rörtảngen (silt) limitation of microphytobenthos has also been found, particularly in sandy sediments (Granéli \& Sundbäck 1985, Flothmann \& Werner 1992). To obtain an indication of the most limiting nutrient in the water body, the IN/IP molar ratio of the winter concentrations of the surface water is often used (e.g. Granéli et al. 1990). Applying this to the Vallda site, a ratio of 26 was found in February but by March this was close to the Redfield ratio (ca 15). The 5 times higher IN winter concentrations at Rörtången resulted in IN/IP ratios of 60 to 90 . suggesting $P$ limitation due to an additional $N$ load, presumably from local sewage outlets. It must be kept in mind, however, that microphytobenthic communities assimilate nutrients from both the overlying water and the sediment pore water (Nilsson \& Sundbäck 1991, Sigmon \& Cahoon 1997).

\section{Sediment type}

The overall differences in the functional variables, such as primary production and community respiration, between the 2 sites were not pronounced. Nutrient fluxes exhibited a temporal rather than a distinct spatial difference between the 2 sites and even for denitrification, which was an order of magnitude higher at the Rörtången site, the difference between

TabIe 2. Annual mean net flux (mean of 11 months, SE in parentheses) of inorganic nitrogen (IN flux), dark - light IN flux ( $\triangle \mathrm{IN}$ flux), calculated nitrogen demand (N demand) of benthic microphytes and total denitrification $D_{\text {tot }}\left(D_{\mathrm{w}}+D_{\mathrm{n}}\right.$ ) in light and dark. Algal demand is based on net primary production, $\mathrm{C} / \mathrm{N}$ ratio of $9 \mathrm{~mol}$ and photosynthetic quotient of 1.2 . All values are expressed as $\mu \mathrm{mol} \mathrm{m}{ }^{-2} \mathrm{~h}^{-1}$. -: uptake, +: efflux of IN

\begin{tabular}{|lllcrrr|}
\hline \multirow{2}{*}{ Stn } & \multicolumn{4}{c}{ Light } & & Dark \\
& IN flux & SIN flux & N demand & $D_{\text {tot }}$ & IN & $D_{\text {tot }}$ \\
\hline Vallda A (sand) & $-6.0(8.1)$ & $14.5(6.4)$ & $152(38)$ & $1.4(0.5)$ & $+8.5(4.5)$ & $1.7(0.4)$ \\
Vallda B (sand) & $-6.9(5.7)$ & $20.1(6.0)$ & $165(40)$ & $1.4(0.5)$ & $+13.2(3.7)$ & $1.5(0.5)$ \\
Rörtången C (silt) & $-4.3(6.4)$ & $30.6(10.2)$ & $60(27)$ & $7.5(2.8)$ & $+26.3(8.2)$ & $18.1(10.1)$ \\
Rörtånegn D (silt) & $-8.0(30.4)$ & $32.0(10.1)$ & $197(71)$ & $11.2(3.5)$ & $+24.0(6.9)$ & $22.8(10.0)$ \\
\hline
\end{tabular}


sites depended on season. The lack of major differences in the magnitude of measured rates was somewhat unexpected considering the different sediment type (particle size, porosity, organic matter content, oxygen penetration; Table 1). However, to a certain degree, the influence of sediment type may have been masked by the heterogeneity at Rörtången. Heterogeneity of the substratum is a general problem when studying shallow-water sediments (Morrisey et al. 1992). A test of spatial variability in our study, using the $\mathrm{chl} a$ content of the sediment, suggested that the main variation was to be found on the site scale, although variation also occurred on a smaller scale (between stations at the silty site), but this was dependent on season.

Sediment type has often been suggested as a major parameter that relates to both the amount and composition of microphytobenthos (Colijn \& Dijkema 1981, Sundbäck 1984), as well as to the magnitude of net oxygen production and nutrient flux (Sundbäck et al. 1991, Reay et al. 1995, Rizzo et al. 1996). This would appear natural, as the sediment type is a result of the degree of sediment movement, determining the balance between erosion and accumulation of material, which in its turn affects the carbon content, remineralisation rate and nutrient availability at the sediment/

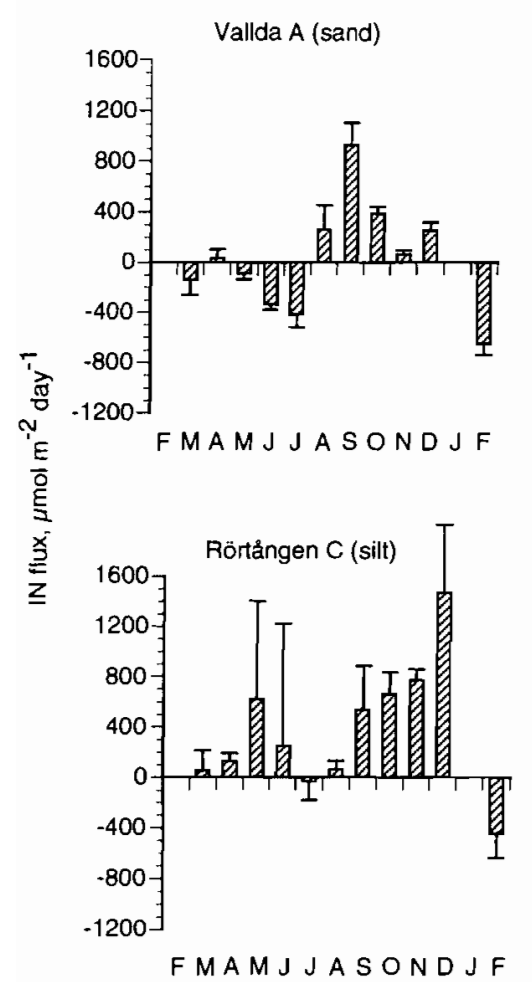

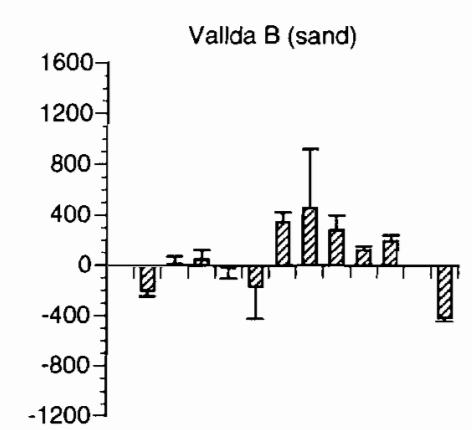

FMAMJJASONDJF

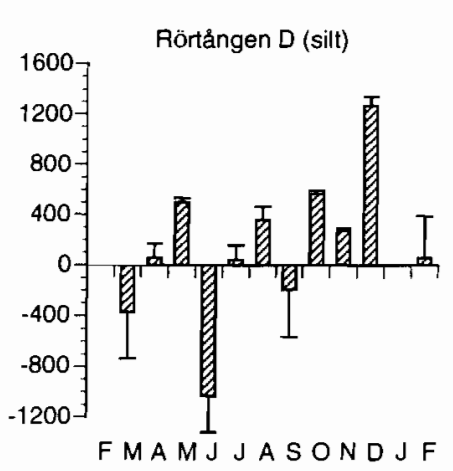

Fig. 5. Daily flux of inorganic nitrogen (IN) $\left(\mathrm{NO}_{3}+\mathrm{NO}_{2}+\mathrm{NH}_{4}\right)$ at Vallda $\operatorname{Stn} A$, Vallda Stn $\mathrm{B}$, Rörtången Stn $\mathrm{C}$ and Rörtången Stn $\mathrm{D}$. Values shown are mean + $\mathrm{SE}(\mathrm{n}=3)$ water interface (e.g. Sloth et al. 1995). Our results suggest that, although sediment type may well determine the major composition of the microalgal community, its biomass and function are less affected, the range of variation between the sites remaining less than a factor of 2 . This agrees with the results by Barranguet et al. (1998), who found that a sandy and a muddy intertidal site were equally productive, and those of Light \& Beardall (1998), who found that sediment type did not explain spatial dissimilarities in chl a content in a large-scale study from a subtidal area. In our study, however, the pattern of temporal variation appeared to be related to the sediment type.

\section{What controls general seasonality?}

A pronounced seasonality is a typical feature of the littoral zone of the brackish Baltic Sea area, including the Kattegat, with frequent ice cover in shallow bays during winter. Thus, temperature can be expected to be one of the main controlling factors in the shallowwater zone. When interpreting temporal variations in our study, it must, however, be kept in mind that despite spatial replication, there was no replication in time; a fact that weakens the discussion on seasonal patterns, particularly for the less predictable silty site (cf. Morrisey et al. 1994). Still, at both sites, oxygen production and community respiration showed a positive significant correlation with temperature. This seasonal pattern, with rapidly increasing production values from May to June, agrees well with the pattern previously found for microphytobenthos in the Baltic Sea area (Wasmund 1986, Sundbäck \& Jönsson 1988, Meyercordt \& Meyer-Reil 1999).

For variables other than oxygen flux, there were significant differences in the seasonal pattern between the 2 sites, with a smoother, unimodal pattern at Vallda, and a more erratic variation at Rörtången. While the seasonality in the sandy sediment appeared to be mainly driven by temperature and irradiance (cf. Rizzo et al. 1996), the silty site appeared to be driven by additional factors superimposed on the seasonal pattern. Rörtången (especially the more exposed Stn C) is probably controlled to a higher degree by stochastic events, mainly sediment resuspension (cf. Schreiber \& Pennock 

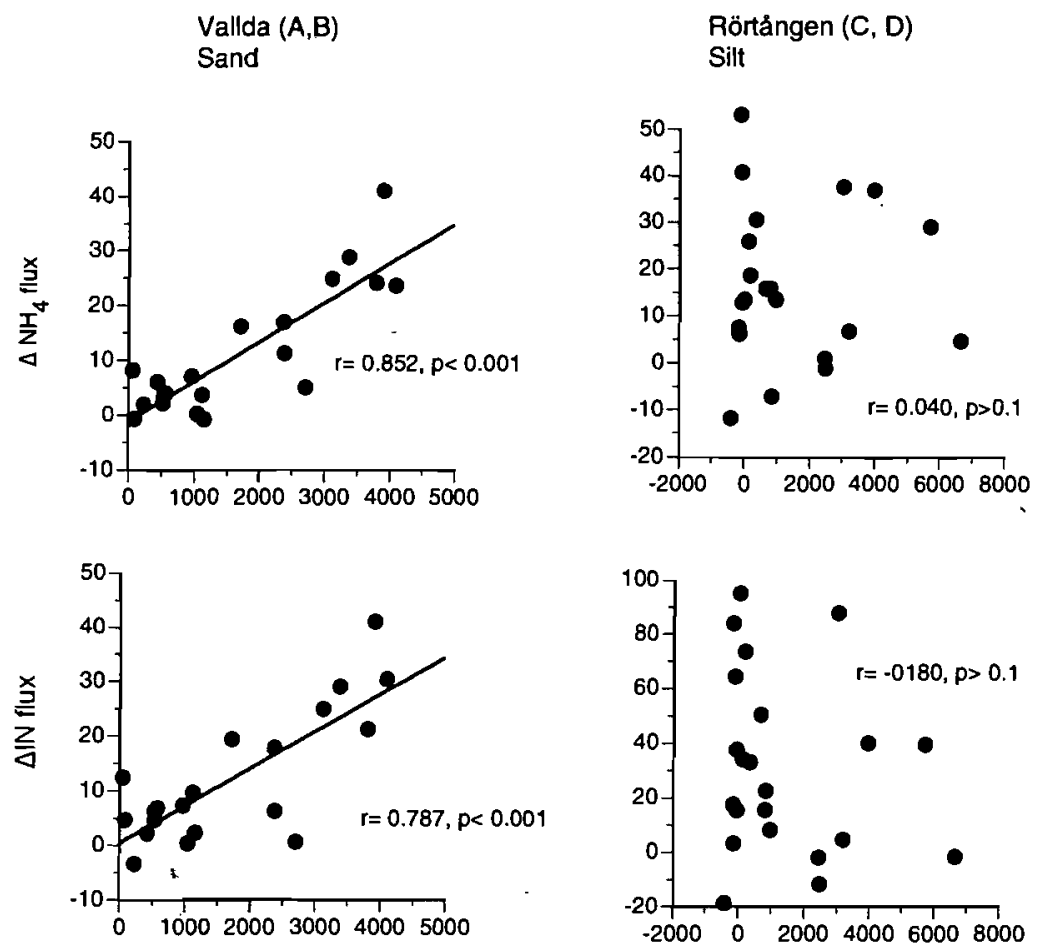

$\mathrm{O}_{2}$ flux in light (NP)

Fig. 6. Correlations between $\Delta \mathrm{O}_{2}$ flux (light - dark flux) and mean monthly values of $\Delta$ fluxes (dark - light flux) of $\mathrm{NH}_{4}, \mathrm{NO}_{3}+\mathrm{NO}_{2}$ and inorganic nitrogen (IN) ( $=\mathrm{NH}_{4}+\mathrm{NO}_{3}+\mathrm{NO}_{2}$ ) for the 2 sites (including 2 stations per site). All values are in $\mu \mathrm{mol} \mathrm{m} \mathrm{m}^{-2} \mathrm{~h}^{-1}$

1995), creating, e.g., local changes in water turbidity and increased nutrient concentrations in the overlying water (Pedersen et al. 1995). An indication of this was seen in the correlation between wind speed and chl $a_{\text {, }}$ suggesting that resuspension followed by resettlement may stimulate microphytobenthos (A.M. pers. obs). While the role of resuspension has been extensively studied for tidal flat microphytobenthos (e.g. Delgado et al. 1991, de Jonge \& Beusekom 1996, MacIntyre \& Cullen 1996), this aspect has gained far less attention in microtidal sediments (Schreiber \& Pennock 1995, Sloth et al. 1996). The more dynamic nature of the silty site is also indicated by the higher mean turnover rate (B/NP, biomass/net production) of the algal community, which was almost twice as high (4 d) for Stn D, when compared to Stns A and B $(7 \mathrm{~d})$. The slow turnover rate $(10 \mathrm{~d})$ of $S \operatorname{Ctn} C$ further emphasises the problem of extreme heterogeneity within the Rörtången site. $\mathrm{B}$ was calculated as mean chl $a \times 30$, and NP as mean daily net production for the entire study period.

Although sediment movement appears to be the main factor accounting for the different patterns between the sites, higher nutrient availability at the silty site may also have counteracted a clear seasonal pattern caused by temperature and light limitation.

Animal activity can also be expected to contribute to the temporal variations of microphytobenthos and sediment/ water nitrogen fluxes through grazing, bioturbation and nutrient excretion (Pelegri \& Blackburn 1994, Rysgaard et al. 1995 and references therein). Macrofauna did not correlate significantly with temperature, but showed a significant positive correlation with both dark $\mathrm{NH}_{4}$ flux ( $\left.\mathrm{p}<0.05\right)$ and algal biomass ( $p<0.001$ ), which may suggest a stimulating effect by fauna. For example, $\mathrm{NH}_{4}$ excretion by cockles has been shown to stimulate microphytobenthos (Lindström Swanberg 1991). The effects of grazers were outside the scope of this study, but grazing by Hydrobia snails, common particularly on the sandy site. may have occurred (Asmus \& Asmus 1985, Duarte \& Cebrián 1996).

\section{Denitrification}

Denitrification rates in this study were higher for the silty sediment than for the sandy sediment. This has also been found by others, and can be explained by, e.g., better availability of carbon and nutrients in the silty sediment (Jensen et al. 1996, Nowicki et al. 1997). In our study the carbon content was $>3$ times higher at the silty site. The low denitrification rates at the sandy Vallda site agreed well with those found for similar littoral sediments in the Gulf of Riga, SE Baltic Sea (Sundbäck et al. 1998), and in the Kattegat (L.-P. Nielsen cited in Lomstein et al. 1998) measured by the same method. The higher rates at the silty Rörtången site agree with the annual range of $D_{\mathrm{n}}$ reported for a microtidal shallow Danish estuary (Rysgaard et al. 1995).

Nitrate concentration has been identified as one of the main factors controlling denitrification in sediments (Seitzinger 1988, Jensen et al. 1996), and $D_{w}$ in this study did indeed correlate well with the $\mathrm{NO}_{3}$ concentration of the overlying water. The fact that $D_{\mathrm{n}}$ generally dominated the denitrification at our sites can be explained by the low $\mathrm{NO}_{3}$ concentrations in the overlying water (cf. Rysgaard et al. 1995).

In coastal sediments it is usual to find maximum rates of denitrification in late winter and spring, with low rates in summer and a second peak in late autumn 
(Jørgensen 1989, Rysgaard et al. 1995). A similar pattern was seen for the dark rates of denitrification measured in our study. The different seasonal denitrification pattern in light at the 2 sites, however, was striking. The autumn peak at Vallda was partly due to an extreme $D_{\mathrm{w}}$ rate triggered by an elevated $\mathrm{NO}_{3}$ concentration (ca $7 \mu \mathrm{M}$ ) in the overlying water that coincided with the denitrification measurements. Others (Joye \& Paerl 1993, Kana et al. 1998) have also found such a rapid response. In spring and summer, the low rates of denitrification in light may be due to $\mathrm{N}$ competition with microalgae during the day in an $\mathrm{N}$-limited situation, as this is the season when microphytobenthic activity is increasing. At the Rörtången site, an elevated $\mathrm{NO}_{3}$ concentration in September (ca $6.5 \mu \mathrm{M}$ ) was reflected as a denitrification peak in the dark, but not in light. The reason for this could be the high oxygen production by microalgae, which pushed the denitrification zone in the sediment deeper, thereby inhibiting $D_{\text {w }}$ (Risgaard-Petersen et al. 1994, Rysgaard et al. 1995, Pind et al. 1997) (see 'Microphytobenthos as a controlling factor' below]. The simultaneous discrepancy in $D_{\mathrm{n}}$ between light and dark at Rörtången may simply be a result of sediment patchiness, as suggested by the high standard error. The higher spring values at Rörtången, being within the same range as the dark values, follow the general pattern found previously for denitrification. This may indicate that $N$ is not as limiting as at Vallda.

\section{Microphytobenthos as a controlling factor}

\section{Effect on fluxes and denitrification}

The microphytobenthos had a significant influence on oxygen fluxes throughout the year and as a result both sites could be categorized as net to highly photoautotrophic (Fig. 4). This classification applied all year round for the sandy Vallda site and may be a typical feature of temperate shallow-water sandy sites (cf. Rizzo et al. 1996). Calculating net annual primary production from oxygen flux values (photosynthetic quotient $=1.2$ ) results in net primary production values between 32 and $104 \mathrm{~g} \mathrm{C} \mathrm{m}^{-2} \mathrm{yr}^{-1}$ for the 2 sites. These values fall well within the range found for both tidal and non-tidal shallow-water sediments, using varying methods (Colijn \& de Jonge 1984, Pinckney \& Zingmark 1993, Schreiber \& Pennock 1995, Kromkamp et al. 1998).

The benthic microphytes had a significant effect on the sediment/water flux of both $\mathrm{NH}_{4}$ and $\mathrm{NO}_{3}+\mathrm{NO}_{2}$, although it was clearer for fluxes of $\mathrm{NH}_{4}$, agreeing with previous findings (Rizzo 1990, Sundbäck et al. 1991, Asmus et al. 1998, Thornton et al. 1999 and references therein). The decrease of the $\mathrm{NH}_{4}$ efflux in light was substantial, corresponding to ca 70 to $100 \%$ of the efflux in dark (mean annual). Net uptake of IN occurred mainly in the spring and summer, reflecting microalgal growth, although a net effect of light was observed almost all year round (February to November) with only a few exceptions during the year for the silty site. A significant correlation between both NP and $\Delta \mathrm{O}_{2}$ flux, and $\Delta \mathrm{NH}_{4}$ and $\Delta \mathrm{IN}$ fluxes corroborates the effect of microphytobenthos for the unimodally seasonal sandy site, but not for the generally more heterogeneous silty site (Fig. 6).

The presence of an active microalgal community at the sediment surface has been found to influence the rate, as well as the vertical zonation, of denitrification both seasonally and diurnally (Risgaard-Petersen et al. 1994, Currin et al. 1996, Lorenzen et al. 1998). Photosynthetic oxygen production has been found to reduce $D_{\mathrm{w}}$, but to stimulate $D_{\mathrm{n}}$ (Risgaard-Petersen et al. 1994) although an exception to this may be seen in summer when competition between algal and bacterial assimilation can occur (Rysgaard et al. 1995). In this study, it appeared that light generally inhibited denitrification. No stimulation of $D_{\mathrm{n}}$ in the light could be proved but this was probably due to the generally low $\mathrm{NO}_{3}$ concentrations found in the in situ water. Rysgaard et al. (1995) also found, in a similar shallow-water environment, that $D_{\mathrm{n}}$ was stimulated only at $\mathrm{NO}_{3}$ concentrations above $20 \mu \mathrm{M}$.

\section{Estimated algal assimilation of $\mathrm{N}$}

In this study, the actual $\mathrm{N}$ uptake and retention by microalgae was not measured directly and we therefore have to rely on theoretical estimations based on primary production in combination with conversion factors. For conversion of $\mathrm{chl}$ a values to algal biomass we have used a C/chl a ratio of 30 , which agrees well with the average $\mathrm{C} / \mathrm{chl}$ a ratio (32) for our silty site, as well as with the $\mathrm{C} / \mathrm{chl}$ a ratios (30 to 40 ) most often applied for microphytobenthos on tidal flats (de Jonge 1980). However, for our sandy site, dominated by epipsammic life forms, the average ratio was lower (mean 18). The better agreement for the silty site with previously published ratios may result from the fact that the species composition (large motile diatoms) was similar to that of tidal flats (cf. Underwood 1994, Brotas \& Plante-Cuny 1998, Paterson et al. 1998). The $\mathrm{C} / \mathrm{chl}$ a ratio of communities dominated by epipsammic species has hardly ever been studied, and we do not currently know whether this difference is real or caused by methodological problems. For the preliminary calculations of $\mathrm{N}$ demand from primary productivity, we have used a $\mathrm{C} / \mathrm{N}$ ratio of 9 . This agrees with 
our own values for sediment microphytobenthos from the Kattegat area (Miles et al. unpubl.), as well as with the mean ratio found for epilithic microalgal communities in the western Baltic Sea (Hillebrand \& Sommer 1997).

The calculated $\mathrm{N}$ demand based on net primary productivity (assuming a photosynthetic quotient of 1.2) resulted in a theoretical mean annual $\mathrm{N}$ demand of ca 152 and $165 \mu \mathrm{mol} \mathrm{m}^{-2} \mathbf{h}^{-1}$ for Stns $A$ and $B$ at the Vallda site and 60 and $197 \mu \mathrm{mol} \mathrm{m}^{-2} \mathrm{~h}^{-1}$ for Stns $C$ and $D$ at the Rörtången site, respectively (Table 2). With the exception of Stn C, these values far exceed (6 to 10 times) the measured IN flux rates ( $\triangle \mathrm{IN}=$ dark - light flux) (Table 2). At Vallda, the calculated $\mathrm{N}$ demand exceeded $\triangle I N$ flux throughout the year, while the estimated demand was occasionally in balance with sediment uptake at Rörtången. However, these calculations in no way estimate the demand for $\mathrm{N}$ by bacteria. Thus, the microalgae were either nitrogen limited or dependent on the pore water as an $\mathrm{N}$ source. The latter hypothesis is supported by the comparison of the outcome of previous enrichment experiments with natural sediment and aIgal communities isolated onto thin sand and agar plates (Nilsson \& Sundbäck 1991, Nilsson et al. 1991).

Could then the initial total local pool of IN support the microalgal biomass when considered on an annual scale? The maximum winter concentration of $\mathrm{NO}_{3}$ in the overlying water was $30 \mu \mathrm{M}$ at Rörtången. With a mean water column of $0.5 \mathrm{~m}$, this infers that $15 \mathrm{mmol} \mathrm{m}{ }^{-2}$ was available for 'new production' (in the sense of Dugdale \& Goering 1967) of microphytobenthos, not accounting for the unknown sediment $\mathrm{N}$ pool and assuming that plankton productivity was negligible because of the shallow water column. Thus, the IN pool in the overlying water would be enough to support the average amount bound to microphytobenthos ( 8 to $11 \mathrm{mmol} \mathrm{N} \mathrm{m}{ }^{-2}$, calculated from chl a) at the silty site. However, at Vallda, the peak winter concentration of $\mathrm{NO}_{3}$ was only $6 \mu \mathrm{M}$ ( $=3.5 \mathrm{mmol} \mathrm{m}^{-2}$ ), which was around one-quarter of the $\mathrm{N}$ bound to microalgal biomass $(15$ to $16 \mathrm{mmol}$ $\mathrm{m}^{-2}$ ). As IN concentrations were very low during the rest of the year, microphytobenthos must rely on efficiently recycled remineralised nitrogen. This conclusion agrees with that of Lomstein et al. (1998), who studied the remineralisation processes in sandy sediment colonized by benthic microphytes in a low- $\mathrm{NO}_{3}$ area in the Kattegat.

Dissolved organic nitrogen (DON) constitutes a potential nitrogen source for microalgae (Antia et al. 1991), such as benthic diatoms, which are able to take up, e.g., free amino acids (Admiraal et al. 1987, Nilsson \& Sundbäck 1996 and references therein). Our flux values for DON, however, should be interpreted with caution, because of methodological problems (see, e.g., Burdige \& Zheng 1998). The DON flux dominated the total flux of $\mathrm{N}$, exceeding the $\mathrm{NH}_{4}$ flux often by an order of magnitude (not shown). A high efflux of DON in combination with low $\mathrm{NH}_{4}$ efflux has also been found by others and can be explained by hydrolysis of organic detritus at the sediment surface, which would lead to a large diffusional loss (Blackburn et al. 1996, Lomstein et al. 1998).

Microalgal retention of nitrogen versus denitrification

Microphytobenthic assimilation and denitrification are both processes that remove dissolved bioavailable $\mathrm{N}$ from the system, although only the latter process does so permanently. However, the magnitude of these 2 processes have only seldom been assessed, or discussed, simultaneously (see, however, Pind et al. 1997). The mean annual $\mathrm{N}$ demand of microphytobenthos in our study was estimated to be 60 to $197 \mu \mathrm{mol} \mathrm{N} \mathrm{m}{ }^{-2} \mathrm{~h}^{-1}$ (Table 2). Although these values are probably underestimations, as they are based on NP, they still exceed denitrification by 1 to 2 orders of magnitude. This preliminary comparison, based on mean hourly rates, suggests that denitrification may have a minor role in cold, particularly sandy, microtidal sediments, at least in the shallowest waters. However, in order to get an ecologically relevant comparison (i.e. days, months, years), and this will be addressed in a separate paper (Sundbäck \& Miles unpubl.). A more accurate comparison may also require other approaches to measure algal $\mathrm{N}$ assimilation, such as a combination of ${ }^{14} \mathrm{C}$ uptake and a good knowledge of the $\mathrm{C} / \mathrm{N}$ ratios of microphytobenthos, or direct measurements of $\mathrm{N}$ uptake using the ${ }^{15} \mathrm{~N}$ technique.

\section{Sediment as sink and source of nitrogen}

Previous measurement of nutrient fluxes in similar shallow-water areas suggested that microtidal sandy sediments may function as a sink for $\mathrm{N}$, at least during summer (e.g. Nilsson et al. 1991, see also Pind et al. 1997). If mean IN flux is considered for the entire study period, all stations in our study were sinks for nitrogen in the light, and sources in the dark (Table 2). Converting hourly values to daily values (using the number of light and dark hours, respectively), shows that the sandy site appears to generally function as a sink for IN during winter, spring and early summer (February to July) (Fig. 5). For the silty site, the pattern is more erratic, with occasional periods of uptake and higher efflux. 


\section{CONCLUSIONS}

The 2 shallow-water microtidal sediment sites studied differed as to sediment characteristics and composition of the microphytobenthic community, and to some degree nutrient status. Some functional features emerged, some of which $(2,3,5,6,7,8)$ are hypothesised to be typical of shallow-water sediments in cold microtidal waters: (1) Although sediment type appears to determine the composition of microphytobenthos, it may not have a crucial effect on the magnitude of its biomass or function. (2) The temporal pattern of the function, on the other hand, is influenced by the sediment type; sandy sediment exhibits a smooth seasonality controlled mainly by temperature and light, while silty microtidal sediments are also controlled by stochastic events superimposed on the seasonal pattern. (3) The microphytobenthos functions as a major controlling factor over the annual cycle by forming communities that are net photoautotrophic throughout the majority of the year. (4) The microphytobenthos controls the nitrogen flux at the sediment surface, the clearest effect being found for $\mathrm{NH}_{4}$ flux, which can be decreased substantially (by up to $100 \%$ ) in light. (5) The results from the sandy site support the idea that sandy systems in low-nitrogen areas can be highly productive through a closed recycling of $N$. (6) Denitrification measurements in light and dark suggest that microphytobenthic activity generally inhibits denitrification in low$\mathrm{N}$ areas. (7) Over the annual cycle, sandy sediment in the light functions as a $\mathrm{N}$ sink during the period winter to early spring. (8) A preliminary calculation of the ratio between theoretical microphytobenthic $\mathrm{N}$ demand and measured denitrification suggests that denitrification may have a minor role as a $\mathrm{N}$ sink in these sediments, particularly in the sandy cold microtidal sediments. However, for ecological relevance, this balance must be considered on a longer time scale than hours.

Acknowledgements. This research has been undertaken in the framework of the NICE project. We acknowledge the support from the European Commission's Marine Science and Technology Programme (MAST III) under contract MAS3CT96-0048. This is ELOISE Contribution No. 146. National funding for the project was received from the Swedish Environmental Protection Agency and NUTEK. Further support was also received from the Swedish Natural Science Research Council (TRAACS analytic system), the Fund of Captain Stenholm and The Royal Society of Arts and Sciences in Göteborg. Riikka Oja provided valuable assistance during summer 1997. The authors also thank Rosa Viejo, Frank Linares, Silvia Gogg, Monica Appelgren and Mireille Consalvey for valuable help in the field.

\section{LITERATURE CITED}

Admiraal W, Riaux-Gobin C, Laane RWPM (1987) Interactions of ammonium, nitrate, and D- and L-amino acids in the nitrogen assimilation of two species of estuarine benthic diatoms. Mar Ecol Prog Ser 40:267-273

Antia NJ, Harrison PJ, Oliveira L (1991) The role of dissolved organic nitrogen in phytoplankton nutrition, cell biology and ecology. Phycologia 30:1-89

Asmus H, Asmus R (1985) The importance of grazing food chain for energy flow and production in three intertidal sand bottom communities of the northern Wadden Sea. Helgol Meeresunters 39:273-301

Asmus RM, Jensen MH, Jensen KM, Kristensen E, Asmus $\mathrm{H}_{\text {, }}$ Wille A (1998) The role of water movement and spatial scaling for measurement of dissolved inorganic nitrogen fluxes in intertidal sediments. Estuar Coast Shelf Sci 46: 221-232

Barranguet C, Kromkamp J, Peene J (1998) Factors controlling primary production and photosynthetic characteris. tics of intertidal microphytobenthos. Mar Ecol Prog Ser 173:117-126

Blackburn TH, Henriksen $\mathrm{K}$ (1983) Nitrogen cycling in different types of sediments from Danish waters. Limnol Oceanogr 28:477-493

Blackburn TH, Hall POJ, Hulth S, Landén A (1996) Organic$\mathrm{N}$ loss by efflux and burial associated with a low efflux of inorganic $\mathrm{N}$ and with nitrate assimilation in Arctic sediments (Svalbard, Norway). Mar Ecol Prog Ser 141: 283-293

Brotas V, Plante-Cuny MR (1998) Spatial and temporal patterns of microphytobenthic taxa of estuarine tidal flats in the Tagus Estuary (Portugal) using pigment analysis by HPLC. Mar Ecol Prog Ser 171:43-57

Burdige DJ, Zheng S (1998) The biogeochemical cycling of dissolved organic nitrogen in estuarine sediments. Limnol Oceanogr 43:1796-1813

Colijn F, de Jonge VN (1984) Primary production of microphytobenthos in the Ems-Dollard estuary. Mar Ecol Prog Ser 14:185-196

Colijn F, Dijkema KS (1981) Species composition of benthic diatoms and distribution of chlorophyll $a$ on an intertidal flat in the Dutch Wadden Sea. Mar Ecol Prog Ser 4:9-21

Currin CA, Joye SB, Paerl HW (1996) Diel rates of $\mathrm{N}_{2}$-fixation and denitrification in a transplanted Spartina alterniflora marsh: implications for $\mathrm{N}$-flux-dynamics. Estuar Coast Shelf Sci 42:597-616

Dalsgaard $T$ (ed) (2000) Protocol handbook for NICE, National Environmental Research Institute. Silkeborg, $62 \mathrm{pp}$

de Jonge VN (1980) Fluctuations in the organic carbon to chlorophyll a ratios for estuarine benthic diatom populations. Mar Ecol Prog Ser 2:345-353

de Jonge VN, van Beusekom JEE (1996) Wind- and tideinduced resuspension of sediment and microphytobenthos from tidal flats in the Ems Estuary. Limnol Oceanogr 40: $766-778$

Delgado M, de Jonge VN, Peletier H (1991) Experiments on resuspension of natural microphytobenthos populations. Mar Biol 108:321-328

Duarte CM, Cebrían J (1996) The fate of marine autotrophic production. Limnol Oceanogr 41:1758-1766

Dugdale RC, Goering JJ (1967) Uptake of new and regenerated forms of nitrogen in primary productivity. Limnol Oceanogr 12:197-206

Flothmann S, Werner I (1992) Experimental eutrophication on an intertidal sandflat: effects on microphytobenthos, meioand macrofauna. In: Colombo G, Ferrari I, Ceccherelli VU (eds) Marine eutrophication and population dynamics. Olsen \& Olsen, Fredensborg, p 93-100

Granéli E, Sundbäck K (1985) The response of planktonic and 
microbenthic algal assemblages to nutrient enrichment in shallow coastal waters, southwèst Sweden. J Exp Mar Biol Ecol 85:253-268

Granéli E, Wallström $\mathrm{K}$, Larsson. U, Granéli W, Elmgren R (1990) Nutrient limitiation of primary production in the Baltic Sea area. Ambio 19:142-151

Grasshoff K, Erhardt M, Kremling K (1983) Methods of seawater analyses, 2nd edn. Verlag Chemie, Weinheinm

Henriksen K, Hansen J, Blackburn TH (1980) The influence of benthic infauna on exchange rates of inorganic nitrogen between sediment and water. Ophelia (Suppl) 1:249-256

Herndl GJ, Peduzzi P, Fanuko N (1989) Benthic community metabolism and microbial dynamics in the Gulf of Trieste (Northern Adriatic Sea). Mar Ecol Prog Ser 53:169-178

Hillebrand H, Sommer U (1997) Response of epilithic microphytobenthos of the Western Baltic Sea to in situ experiments with nutrient enrichment. Mar Ecol Prog Ser 160: $35-46$

Jensen KM, Jensen MH, Kristensen E (1996) Nitrification and denitrification in Wadden Sea sediments (Koenigshafen, Island of Sylt, Germany) as measured by nitrogen isotope pairing and dilution. Aquat Microb Ecol 11:181-191

Jørgensen KS (1989) Annual pattern of denitrification and nitrate ammonification in estuarine sediment. Appl Environ Microbiol 55:1841-1847

Joye SB, Paerl HW (1993) Contemporaneous nitrogen fixation and denitrification in intertidal microbial mats: rapid response to runoff events. Mar Ecol Prog Ser 94:267-274

Kana TM, Sullivan MB, Cornwell JC, Groszkowski KM (1998) Denitrification in estuarine sediments determined by membrane inlet mass spectrometry. Limnol Oceanogr 43 : $334-339$

Krom MD (1991) Importance of benthic productivity in controlling the flux of dissolved inorganic nitrogen through the sediment-water interface in a hypertrophic marine ecosystem. Mar Ecol Prog Ser 78:163-172

Kromkamp J, Barranguet C, Peene J (1998) Determination of microphytobenthos PSIl quantum efficiency and photosynthetic activity by means of variable chlorophyll fluorescence. Mar Ecol Prog Ser 162:45-55

Light BR, Beardall J (1998) Distribution and spatial variation of benthic microalgal biomass in a temperate, shallowwater marine system. Aquat Bot 61:39-54

Lindström Swanberg I (1991) The influence of the filter-feeding bivalve Cerastoderma edule $\mathrm{L}$. on microphytobenthos: a laboratory study. J Exp Mar Biol Ecol 151:93-111

Lomstein $\mathrm{BA}_{1}$ Jensen AGU, Hansen $\mathrm{JW}$, Andreasen JB, Hansen LS, Berntsen J, Kunzendorf $H$ (1998) Budgets of sediment nitrogen and carbon cycling in the shallow water of Knebel Vig, Denmark. Aquat Microb Ecol 14:69-80

Lorenzen CJ (1967) Determination of chlorophyll and pheopigments: spectrophotometric equations. Limnol Oceanogr 12:343-346

Lorenzen J, Larsen LH, Kjaer T, Revsbech NP (1998) Biosensor determination of the microscale distribution of nitrate, nitrate assimilation, nitrification, and denitrification in a diatom-inhabited freshwater sediment. Appl Environ Microbiol 64:3264-3269

MacIntyre HL, Cullen JJ (1996) Primary production by suspended and benthic microalgae in a turbid estuary: timescales of variability in San Antonio Bay, Texas. Mar Ecol Prog Ser 145:245-268

Marinelli RL, Jahnke RA, Craven DB, Nelson JR, Eckman JE (1998) Sediment nutrient dynamics on the South Atlantic Bight continental shelf. Limnol Oceanogr 43:1305-1320

Meyercordt J, Meyer-Reil LA (1999) Primary production of benthic microalgae in two shallow coastal lagoons of dif- ferent trophic status in the southern Baltic Sea. Mar Ecol Prog Ser 178:179-191

Morrisey DJ, Howitt L, Underwood AJ, Stark JS (1992) SpatiaI variation in soft-sediment benthos. Mar Ecol Prog Ser 81: 197-204

Morrisey DJ, Underwood AJ, Stark JS, Howitt L (1994) Temporal variation in concentrations of heavy metals in marine sediments. Esuar Coast Shelf Sci 38:271-282

Nielsen LP (1992) Denitrification in sediment determined from nitrogen isotope pairing. FEMS Microbiol Ecol 86 $357-362$

Nilsson C, Sundbäck K (1991) Growth and nutrient uptake studied in sand-agar microphytobenthic communities. J Exp Mar Biol Ecol 153:207-226

Nilsson C, Sundbäck K (1996) Amino acid uptake by natural benthic microalgal assemblages studied by microautoradiography. Hydrobiologia 332:119-129

Nilsson $P$, Jönsson B, Lindström Swanberg I, Sundbäck K (1991) Response of a marine shallow-water sediment system to an increased load of inorganic nutrients. Mar Ecol Prog Ser 71:275-290

Nixon SW (1995) Coastal marine eutrophication: a definition, social causes, and future concerns. Ophelia 41:199-219

Nowicki BL, Requintina E, Van Keuren D, Kelly JR (1997) Nitrogen losses through sediment denitrification in Boston harbor and Massachusetts Bay. Estuaries 20:626-639

Paterson DM, Wiltshire $\mathrm{KH}$, Miles A, Blackburn J, Davidson I, Yates MG, McGrorty S, Eastwood JA (1998) Microbiological mediation of spectral reflectance from intertidal cohesive sediments. Limnol Oceanogr 43:1207-1221

Pedersen MF, Borum J (1993) An annual nitrogen budget for a seagrass Zostera marina population. Mar Ecol Prog Ser 101:169-177

Pedersen OB, Christiansen C, Laursen MB (1995) Windinduced long term increase and short term fluctuations of shallow water suspended matter and nutrient concentrations, Ringkøbing Fjord, Denmark. Ophelia 41:273-287

Pelegri SP, Blackburn TH (1994) Bioturbation effects of the amphipod Corophium volutator on microbial nitrogen transformations in marine sediments. Mar Biol 121: 253-258

Pihl L, Magnusson G, Isaksson I, Wallentinus I (1996) Distribution and growth dynamics of ephemeral macroalgae in shallow bays on the Swedish west coast. J Sea Res 35: 169-180

Pinckney JL, Zingmark RG (1993) Modeling the annual production of intertidal benthic microalgae in estuarine ecosystems. J Phycol 29:396-407

Pind A, Risgaard-Petersen N, Revsbech NP (1997) Denitrification and microphytobenthic $\mathrm{NO}_{3}{ }^{-}$consumption in a Danish lowland stream: diurnal and seasonal variation. Aquat Microb Ecol 12:275-284

Reay WG, Gallagher DL, Simmons GM Jr (1995) Sedimentwater column oxygen and nutrient fluxes in nearshore environments of the lower Delmarva Peninsula, USA. Mar Ecol Prog Ser 118:215-227

Revsbech NP (1989) An oxygen microelectrode with a guard cathode. Limnol Oceanogr 34:474-478

Risgaard-Petersen N, Rysgaard S, Nielsen LP, Revsbech NP (1994) Diurnal variation of denitrification and nitrification in sediments colonized by benthic microphytes. Limnol Oceanogr 39:573-579

Rizzo WM (1990) Nutrient exchanges between the water column and a subtidal benthic microalgal community. Estuaries 13:219-226

Rizzo WM, Lackey GJ, Christian RR (1992) Significance of euphotic, subtidal sediments to oxygen and nutrient 
cycling in a temperate estuary. Mar Ecol Prog Ser 86: $51-61$

Rizzo WM, Dailey SK, Lackey GJ, Christian RR, Berry BE, Wetzel RL (1996) A metabolism-based trophic index for comparing the ecological values of shallow-water sediment habitats. Estuaries 19:247-256

Rosenberg $R$, Elmgren $R$, Fleischer $S$, Jonsson P, Persson G, Dahlin $H$ (1990) Marine eutrophication case studies in Sweden. Ambio 19:102-108

Rysgaard S, Christensen PB, Nielsen LP (1995) Seasonal variation in nitrification and denitrification in estuarine sediment colonized by benthic microalgae and bioturbating infauna. Mar Ecol Prog Ser 126:111-121

Schreiber RA, Pennock JR (1995) The relative contribution of benthic microalgae to total microalgal production in a shallow sub-tidal estuarine environment. Ophelia 42: $335-352$

Seitzinger SP (1988) Denitrification in freshwater and coastal marine ecosystems: ecological and geochemical significance. Limnol Oceanogr 33:702-724

Sigmon DE, Cahoon LB (1997) Comparative effects of benthic microalgae and phytoplankton on dissolved silica fluxes. Aquat Microb Ecol 13:275-284

Sloth NP, Blackburn H, Hansen LS, Risgaard-Peteresen N, Lomstein BA (1995) Nitrogen cycling in sediment with different organic loading. Mar Ecol Prog Ser 116:163-170

Sloth NP, Riemann B, Nielsen LP, Blackburn HT (1996) Resilience of pelagic and benthic microbial communities to sediment resuspension in a coastal ecosystem, Knebel Vig, Denmark. Estuar Coast Shelf Sci 42:405-415

Strickland JD, Parsons TR (1972) A practical handbook of seawater analysis, 2nd edn. Bull Fish Res Board Can 167

Sundbäck K (1984) Distribution of microbenthic chlorophyll-a and diatom species related to sediment characteristics. Ophelia (Suppl) 3:229-246

Sundbäck K, Jönsson B (1988) Microphytobenthic productivity and biomass in sublittoral sediments of a stratified bay, southeastern Kattegat. J Exp Mar Biol Ecol 122:63-81

Sundbäck K, Enoksson V, Granéli W, Pettersson K (1991) Influence of sublittoral microphytobenthos on the oxygen

Editorial responsibility: Otto Kinne (Editor),

Oldendorf/Luhe, Germany and nutrient flux between sediment and water: a laboratory continuous-flow study. Mar Ecol Prog Ser 74:263-279

Sundbäck K, Nilsson P, Nilsson C, Jönsson B (1996) Balance between autotrophic and heterotrophic components and processes of sandy sediments: a field study. Estuar Coast Shelf Sci 43:689-706

Sundbäck K, Nilsson C, Stockenberg A (1998) Microphytobenthic primary productivity and bacterial nitrogen turnover in the littoral sediments of the Gulf of Riga. Final Report, Nordic Council of Ministers, Göteborg

Thornton DCO, Underwood GJC, Nedwell DB (1999) Effect of illumination and emersion period on the exchange of ammonium across the estuarine sediment-water interface. Mar Ecol Prog Ser 184:11-20

Underwood AJ (1997) Experiments in ecology. Cambridge University Press, Cambridge

Underwood GJC (1994) Seasonal and spatial variation in epipelic diatom assemblages in the Severn Estuary. Diatom Res 9:451-472

Valderrama JC (1981) The simultaneous analysis of total nitrogen and total phosphorus in natural water. Mar Chemı 10:109-122

van Luijn $F$, van der Molen DT, Luttmer WJ, Boers PCM (1995) Influence of benthic diatoms on the nutrient release from sediments of shallow lakes recovering from eutrophication. Wat Sci Technol 32:89-97

Viaroli P, Bartoli M, Bondavalli C, Christian RR (1996) Macrophyte communities and their impact on benthic fluxes of oxygen, sulphide and nutrients in shallow eutrophic environments. Hydrobiologia 329:105-119

Wasmund $N$ (1986) Ecology and bioproduction in the microphytobenthos of the chain of shallow inlets (Boddens) south of the Darss-Zingst Peninsula (Southern Baltic Sea). Int Rev Ges Hydrobiol 71:153-178

Wiltshire KH (1992) The influence of microphytobenthos on oxygen and nutrient fluxes between eulittoral sediments and associated water phases in the Elbe Estuary. In: Colombo G, Ferrari I, Ceccherelli VU (eds) Marine eutrophication and population dynamics. Olsen \& Olsen, Fredensborg, p 63-70

Submitted: August 27, 1999; Accepted: January 7, 2000 Proofs received from author(s): June 14, 2000 